\title{
Regeneration of Species of Natural Flora of the French Antilles Under Plantation Forests of Mahoganis (Swietenia Macrophylla and Aubrevilleana): First Data, the Case of Martinique
}

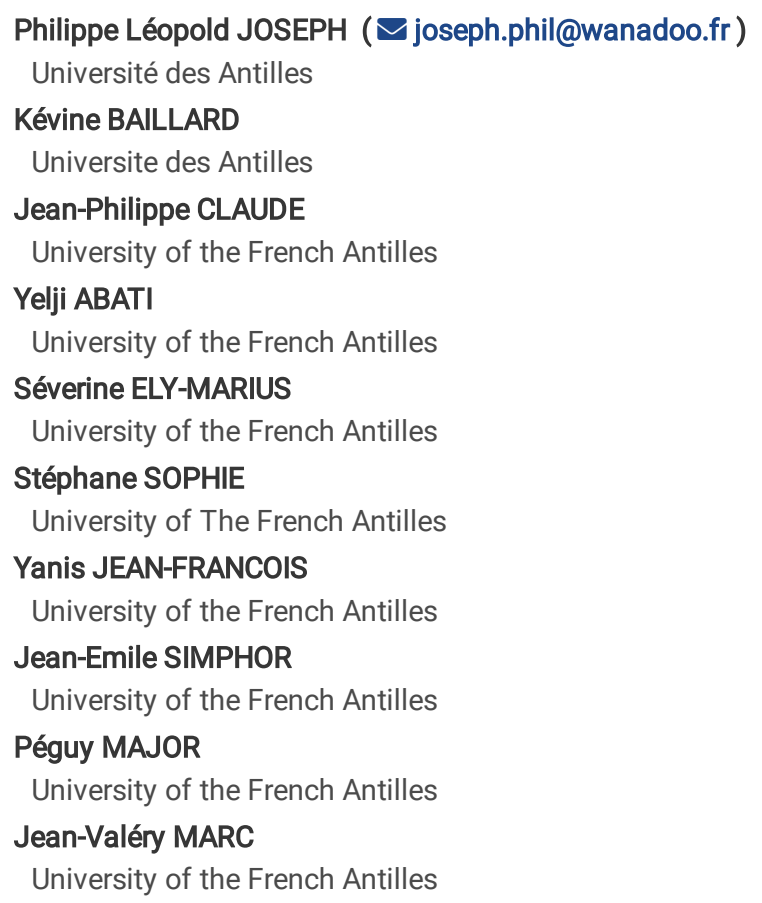

Research

Keywords: Martinique, bioclimates, Swietenia, regeneration, forest, phytocenoses, anthropisation, reforestation

Posted Date: July 22nd, 2020

DOI: https://doi.org/10.21203/rs.3.rs-42036/v1

License: (c) (i) This work is licensed under a Creative Commons Attribution 4.0 International License. Read Full License 


\section{Abstract}

\section{Background}

In many geographic areas influenced by tropical and temperate climates, natural forest ecosystems have been destroyed in favour of plantations of allochthonous trees which are economically profitable for different aspects of the timber industry. Some of these mature plantations degrade the soils and inhibit the regenerations of local flora species; others, due to the physical constraints which they impose, can contribute to the installation and the morphogenetic development of autochthonous taxa. The plantations of Swietenia macrophylla and Swietenia aubrevilleana (Mahoganys) in the Lesser Antilles are part of these processes.

\section{Methods}

To study the regeneration methods of forest plant species native to Martinique under plantations of Mahoganys, we carried out surveys in thirteen transects (stations) influenced by humid and subhumid bioclimates.

\section{Results}

The results showed that affine natural flora species from various stages of the plant succession colonise the plots of mature Mahoganys.

\section{Conclusions}

This study shows that mature plantations of not very competitive introduced forest species can greatly accelerate phytocenotic succession and increase specific richness. It is therefore possible to use these introduced species (Swietenia macrophylla and Swietenia aubrevilleana) in reforestation processes of Lesser Antilles biotopes of sylvan potentiality degraded by anthropisation.

\section{Background}

The domestication of species for survival and societal development is common to all civilisations (Hawkes, Maxted and Ford-Lloyd 2000; Gremillion 1997; Terrell at al. 2003). These species have enabled different peoples to ensure their longevity in all living environments (Crawford 2006; Bar-Yosef 2017; Simons and Leakey 2004). Over ten thousand years ago, the neolithic revolution linked to the birth of agriculture resulting from the gradual or accidental domestication of plants and animals was a turning point in the evolution of humanity (Smith 1997; Borrell, Junno and Barceló 2015; Reed 2011; Gupta 2004; Erickson et al. 2005; Purugganan and Fuller 2009; Colunga-GarcíaMarín and Zizumbo-Villarreal 2004). From this period up to today, the transition from subsistence farming to production farming has led to a huge increase in man's impact on ecosystems (Montoya et al. 2020; Pagán Jiménez 2011 and 2013; Clement et al. 2010; Levis at al. 2017; Quinton et al. 2010; DeFries et al. 2010; Gignoux, Henn and Mountain 2011). With the economic growth of societies and of their demography, what are known as technological plant species relating to the construction, woodworking, carpentry, paper-making and dyeing sectors have been domesticated as well as useful plant food species. (Parker et al. 2020; Jain and Singh 1999; Evans 1992; Evans and Turnbull 2004; Fredericksen and Putz 2003; Olschewski and Benítez 2010). On a global scale, the production of some of these plants which can be extremely commercial have led to and still lead to the conversion of natural phytocenoses into agrocenoses: often the species used are allochthonous species (Ivantsova et al. 2020; Gastó, Subercaseaux and Vera 2012; Sewerniak 2016; Silantyeva et al. 2020; Baillard 2016; Castilla-Beltrán et al. 2019; Fritz et al. 2015). Forestry in tropical and temperate zones, by means of plantation forests, is a significant example (Lamberg and Ojala 2006; Tubiello et al. 2015; Evans 1992; Wingfield et al. 2002; Haggar, Briscoe and Butterfield 1998). While generating lively debates relating to the global ecological balance, the timber sector is an important component of the global economy and affects the ecosystemic resilience of tropical regions in particular (Arets et al. 2011; Banin et al. 2014; Furukawa et al. 2015; Nishijima et al. 2016; Meyfroidt, Rudel and Lambin 2010; Chaudhary, Carrasco and Kastner 2017). The Lesser Antilles are also subject to the process of degradation of the original forest environments in favour of exotic tree plantations [Huguet and Marie 1951; De la Barba Francis 1991; Little, Woodbury and Wadsworth 1974; Francis and Lowe 2000; Norghauer et al. 2011 (Fig. 1)]. Between the end of the 17th century and the beginning of the 18th century, species of the genus Swietenia named Mahoganis were introduced to the French Antilles for wooded resources intended for carpentry (Mayhew et al. 2003; Walters and Hansen 2013; Nelson et al. 2011; Cano Ortiz et al. 2018). Mahoganis were planted on plots cleared of natural vegetation and on some abandoned agricultural land (Krishna and Maurya 2018; Stehlé 1957; Howard 1995; Weaver, Valenta and Officer 1985). In Martinique, the National Forestry Office (ONF in the French acronym) oversees the entire Mahoganis production chain and for more than a century, Mahoganis plantations have been carried out throughout Martinique. Currently, certain plots of Mahoganis over 40 years old are not exploited and their crowns bring about particular internal eco-climatic conditions. In this study, the research protocol is based on trasnsects located in different plots of Mahoganis in order to inventory the populations of autochthonous species (Fig. 2). It is ultimately a question of showing the role of the structure of these mature Mahoganis plantation forests in the installation and development of species of native ligneous flora, especially those from the advanced stages of plant succession. What are the mesological factors that condition the regeneration of extra- and intra-forest autochthonous ligneous species? What are the distribution methods of the species populations? What are the causes of the qualitative stational differentiation of the species?

\section{Materials}

\section{General biophysical characteristics}


Martinique, like the other Lesser Antilles, stems from an intra-oceanic subduction which gradually constructed its contrasting geomorphology (Garmon, Allen, and Groom 2017; Costa, Audin and Benavente 2009). The different topographical facies that result from it modify the structure of the main climatic factors and contribute to the considerable diversity of the biotopes (Triantis et al. 2003). Orographic rain is the key factor of the plant colonisation (DeWalt, Ickes and James 2016; Howard 1962). This leads to, from the lowlands to the mountain peaks, bioclimates which differ from the altitudinal point of view between the windward slope (eastern slope) and the leeward slope (western slope). This bioclimatic staging is a staging of phytocenotic potentiality. Indeed, from the littoral to the altitudes where sylva can install themselves, we find in particular: the lower tropical seasonal evergreen forest in its most xeric facies, the typical tropical seasonal evergreen forest, the sub-montane tropical ombrophilous forest and the montane tropical ombrophilous forest. Ecotones allow for the transition between these potential sylvan types. Generally speaking, and regardless of the plant stages, which are therefore bioclimatic, the plant cover is a patchwork of phytocenoses of different structure, specific composition and ages. Originally, species of the genus Swietenia from Martinique were planted in the bioclimates mentioned above for the production of precious wood.

Main botanical and phytogeographical characteristics of the species of the genus Swietenia. From a phyllogenetic point of view and in ascending manner, the genus Swietenia (Jacq.) belongs to the Family of Meliaceae, the Order of Sapindales, the Class of Magnoliopsida (Dycotyledon), the Division of Angiosperms (Magnoliophyta) and the Kingdom Plantae. The Genus Swietenia comprises five species, all native to tropical America (Krisnawati, Kallio and Kanninen 2011; Snook 1996, York 2012; Fig. 3). However, four of them have been introduced into numerous geographic regions of the intertropical zone [Castañeda-Posadas and Cevallos-Ferriz 2007 (Fig. 3)]. Swietenia aubrevilleana is the result of a hybridisation between macrophylla and mahagoni and is present mainly in certain islands of the archipelago of the Antilles (Brown, Jennings and Clements 2003; Gleason and Panshin 1936; Mabberley 1982). Swietenia mahagoni, macrophylla and aubrevilleana are the only species that are present in Martinique (Fig. 4). From the physiognomic point of view, they have a strong resemblance, but aspects pertaining to the foliar unit and the flowers easily differentiate them (Fig. 4). In adulthood these trees can peak at 40 metres in height with sections at 1.33 metres from the ground ranging from 1.5 to 2.5 metres and ensuring their morphogenetic development on soils conditioned by humid, humid subhumid and dry subhumid bioclimates (Fig. 4).

\section{Study stations, mesological factors, potential forest types and stages of evolution.}

The floristic survey stations were chosen from within mature Mahoganis plantation forests and are located along an altitudinal gradient from $258 \mathrm{~m}$ to $400 \mathrm{~m}$. They are under the influence of hyper-humid, humid and subhumid bioclimates (Table 1a) corresponding to a tiering of mesological factors which condition particularly tropical montane, tropical sub-montane and tropical seasonal evergreen phytocenoses. Associated with the different types of vegetation are soils such as andosols, fersiallitic soils and vertisols (Tables $1 \mathrm{a}$ and $\mathrm{b}$ ). The average annual temperatures measured using meteorological stations close to the floristic survey units (Fig. 2) vary between $23^{\circ} \mathrm{C}$ and $25^{\circ} \mathrm{C}$ with minimums and maximums of between $20{ }^{\circ} \mathrm{C}$ and $23^{\circ} \mathrm{C}$ and between $27^{\circ} \mathrm{C}$ and $29^{\circ} \mathrm{C}$ (Tables $1 \mathrm{a}$ and b). The annual rainfall, which is the factor which characterises the bioclimates by influencing the types of plant ecosystems, varies between $2613.1 \mathrm{~mm}$ and $3869.6 \mathrm{~mm}$ with significant seasonal differences (Tables $1 \mathrm{a}$ and $\mathrm{b}$ ). The number of days with rain during the wet and dry period indicates that the study stations are in rainy areas (Tables $1 a$ and $b$ ). The latter are characterised by annual insolation levels and daily global radiation levels which are among the lowest in Martinique (Tables 1a and b). These aforementioned features are consubstantial with a high annual maximum humidity (100\%) and with an annual evapotranspiration of between $1550 \mathrm{~mm}$ and $1600 \mathrm{~mm}$. 
Table 1

a Mesological conditions of the survey stations

\begin{tabular}{|c|c|c|c|c|c|c|c|c|c|c|}
\hline Number & Stations & Bioclimates & $\begin{array}{l}\text { Altitude } \\
\text { (metres) }\end{array}$ & $\begin{array}{l}\text { Average } \\
\text { minimum } \\
\text { annual } \\
\text { temperature } \\
\left({ }^{\circ} \mathrm{C}\right)\end{array}$ & $\begin{array}{l}\text { Average } \\
\text { maximum } \\
\text { annual } \\
\text { temperature } \\
\left({ }^{\circ} \mathrm{C}\right)\end{array}$ & $\begin{array}{l}\text { Average } \\
\text { annual } \\
\text { temperature } \\
\left({ }^{\circ} \mathrm{C}\right)\end{array}$ & $\begin{array}{l}\text { Annual } \\
\text { insolation } \\
\text { (number } \\
\text { of hours) }\end{array}$ & $\begin{array}{l}\text { Annual } \\
\text { rainfall } \\
(\mathrm{mm})\end{array}$ & $\begin{array}{l}\text { Average } \\
\text { rainfall } \\
\text { for the } \\
\text { three } \\
\text { driest } \\
\text { months } \\
\text { (mm): } \\
\text { February, } \\
\text { March, } \\
\text { April }\end{array}$ & $\begin{array}{l}\text { Average } \\
\text { rainfall for } \\
\text { the three } \\
\text { wettest } \\
\text { months } \\
\text { (m): } \\
\text { August, } \\
\text { September, } \\
\text { October }\end{array}$ \\
\hline 1 & $\begin{array}{l}\text { Sainte- } \\
\text { Marie } 1 \\
\text { (S-M1) }\end{array}$ & Humid & 258 & 21.2 & 28.1 & 24 & 2300 & 3869.6 & 500 & 1100 \\
\hline 2 & $\begin{array}{l}\text { Sainte- } \\
\text { Marie } 2 \\
(\mathrm{~S}-\mathrm{M} 2)\end{array}$ & Humid & 214 & 21.2 & 28.5 & 24 & 2300 & 3812.8 & 500 & 1100 \\
\hline 3 & $\begin{array}{l}\text { Laricher } 1 \\
(\text { La-1) }\end{array}$ & Humid & 322 & 21.1 & 28.2 & 24 & 2300 & 3315.6 & 500 & 1000 \\
\hline 4 & $\begin{array}{l}\text { Laricher } 2 \\
\text { (La-2) }\end{array}$ & Humid & 193 & 21.7 & 28.7 & 24 & 2300 & 3122.7 & 500 & 1000 \\
\hline 5 & $\begin{array}{l}\text { Trou } \\
\text { Matelot } \\
(\mathrm{TM})\end{array}$ & $\begin{array}{l}\text { Hyper } \\
\text { humid }\end{array}$ & 481 & 20.4 & 27.7 & 24 & 2300 & 4213.2 & 600 & 1100 \\
\hline 6 & $\begin{array}{l}\text { Gros } \\
\text { Morne } 1 \\
\text { (G-M1) }\end{array}$ & Humid & 328 & 20.8 & 28.1 & 25 & 2300 & 3930.8 & 600 & 1100 \\
\hline 7 & $\begin{array}{l}\text { Gros } \\
\text { Morne } 2 \\
\text { (G-M2) }\end{array}$ & $\begin{array}{l}\text { Hyper } \\
\text { humid }\end{array}$ & 473 & 20.4 & 27.7 & 23 & 2300 & 4213.2 & 600 & 1100 \\
\hline 8 & $\begin{array}{l}\text { Montravail } \\
(\mathrm{Mt})\end{array}$ & $\begin{array}{l}\text { Humid } \\
\text { subhumid }\end{array}$ & 281 & 22.3 & 28.3 & 24 & 2700 & 1965.3 & 200 & 600 \\
\hline 9 & $\begin{array}{l}\text { Fond } \\
\text { Lahaye } 1 \\
\text { (FL1) }\end{array}$ & $\begin{array}{l}\text { Humid } \\
\text { subhumid }\end{array}$ & 168 & 21.3 & 29.1 & 25 & 2600 & 1748.6 & 300 & 900 \\
\hline 10 & $\begin{array}{l}\text { Fond } \\
\text { Lahaye } 2 \\
\text { (FL2) }\end{array}$ & $\begin{array}{l}\text { Humid } \\
\text { subhumid }\end{array}$ & 132 & 21.3 & 29.1 & 25 & 2600 & 1748.6 & 300 & 900 \\
\hline 11 & $\begin{array}{l}\text { Absalon } 1 \\
\text { (Ab1) }\end{array}$ & Humid & 443 & 20.2 & 26.8 & 24 & 2400 & 2613.1 & 500 & 1000 \\
\hline 12 & $\begin{array}{l}\text { Absalon } 2 \\
\text { (Ab2) }\end{array}$ & Humid & 387 & 20.2 & 26.8 & 24 & 2400 & 2613.1 & 500 & 1000 \\
\hline 13 & $\begin{array}{l}\text { Absalon } 3 \\
\text { (Ab3) }\end{array}$ & Humid & 400 & 20.2 & 26.8 & 24 & 2400 & 2613.1 & 500 & 1000 \\
\hline
\end{tabular}


Table 1

b Mesological conditions of the survey stations and inventory areas

\begin{tabular}{|c|c|c|c|c|c|c|c|c|c|}
\hline No. & Stations & $\begin{array}{l}\text { Survey } \\
\text { areas } \\
(\mathrm{Sr}, \\
\left.\mathrm{m}^{2}\right)\end{array}$ & $\begin{array}{l}\text { Percentage of } \\
\text { days with } \\
\text { significant rain } \\
\text { (Carême-Lent) }\end{array}$ & $\begin{array}{l}\text { Percentage } \\
\text { of days with } \\
\text { significant } \\
\text { rain (winter) }\end{array}$ & $\begin{array}{l}\text { Potential annual } \\
\text { evapotranspiration } \\
\text { (mm) }\end{array}$ & $\begin{array}{l}\text { Minimum } \\
\text { monthly } \\
\text { relative } \\
\text { humidity } \\
(\%)\end{array}$ & $\begin{array}{l}\text { Maximum } \\
\text { monthly } \\
\text { relative } \\
\text { humidity } \\
(\%)\end{array}$ & $\begin{array}{l}\text { Average } \\
\text { cumulative } \\
\text { daily global } \\
\text { radiation } \\
\text { (Joules } / \mathrm{cm}^{2} \text { ) }\end{array}$ & $\begin{array}{l}\text { Type of } \\
\text { soil }\end{array}$ \\
\hline 1 & $\begin{array}{l}\text { Sainte- } \\
\text { Marie } 1 \\
\text { (S-M1) }\end{array}$ & 250 & 50 & 60 & 1550 & 50 & 100 & 55599 & $\begin{array}{l}\text { Allophanic } \\
\text { soils } \\
\text { (Andosols) }\end{array}$ \\
\hline 2 & $\begin{array}{l}\text { Sainte- } \\
\text { Marie } 2 \\
\text { (S-M2) }\end{array}$ & 525 & 50 & 60 & 1550 & 50 & 100 & 55599 & $\begin{array}{l}\text { Allophanic } \\
\text { soils } \\
\text { (Andosols) }\end{array}$ \\
\hline 3 & $\begin{array}{l}\text { Laricher } 1 \\
(\text { La-1) }\end{array}$ & 800 & 50 & 60 & 1550 & 50 & 100 & 55599 & $\begin{array}{l}\text { Allophanic } \\
\text { soils } \\
\text { (Andosols) }\end{array}$ \\
\hline 4 & $\begin{array}{l}\text { Laricher } 2 \\
(\text { La-2) }\end{array}$ & 900 & 50 & 60 & 1550 & 50 & 100 & 55599 & $\begin{array}{l}\text { Brown } \\
\text { soils- } \\
\text { Rusty to } \\
\text { Halloysite }\end{array}$ \\
\hline 5 & $\begin{array}{l}\text { Trou } \\
\text { Matelot } \\
\text { (TM) }\end{array}$ & 1050 & 60 & 70 & 1525 & 50 & 100 & 55599 & $\begin{array}{l}\text { Allophanic } \\
\text { soils } \\
\text { (Andosols) }\end{array}$ \\
\hline 6 & $\begin{array}{l}\text { Gros } \\
\text { Morne } 1 \\
(\mathrm{G}-\mathrm{M} 1)\end{array}$ & 480 & 60 & 70 & 1525 & 50 & 100 & 55599 & $\begin{array}{l}\text { Allophanic } \\
\text { soils } \\
\text { (Andosols) }\end{array}$ \\
\hline 7 & $\begin{array}{l}\text { Gros } \\
\text { Morne } 2 \\
(\mathrm{G}-\mathrm{M} 2)\end{array}$ & 440 & 60 & 70 & 1525 & 50 & 100 & 55599 & $\begin{array}{l}\text { Allophanic } \\
\text { soils } \\
\text { (Andosols) }\end{array}$ \\
\hline 8 & $\begin{array}{l}\text { Montravail } \\
\text { (Mt) }\end{array}$ & 400 & 30 & 50 & 1600 & $(-)$ & $(-)$ & $(-)$ & $\begin{array}{l}\text { Fersiallitic } \\
\text { soils }\end{array}$ \\
\hline 9 & $\begin{array}{l}\text { Fond } \\
\text { Lahaye } 1 \\
\text { (FL1) }\end{array}$ & 700 & 40 & 50 & 1700 & 48 & 100 & 53720 & Vertisols \\
\hline 10 & $\begin{array}{l}\text { Fond } \\
\text { Lahaye } 2 \\
\text { (FL2) }\end{array}$ & 1000 & 40 & 50 & 1700 & 48 & 100 & 53720 & Vertisols \\
\hline 11 & $\begin{array}{l}\text { Absalon } 1 \\
\text { (Ab1) }\end{array}$ & 700 & 50 & 60 & 1600 & 48 & 100 & 53720 & $\begin{array}{l}\text { Allophanic } \\
\text { soils } \\
\text { (Andosols) }\end{array}$ \\
\hline 12 & $\begin{array}{l}\text { Absalon } 2 \\
\text { (Ab2) }\end{array}$ & 700 & 50 & 60 & 1600 & 48 & 100 & 53720 & $\begin{array}{l}\text { Allophanic } \\
\text { soils } \\
\text { (Andosols) }\end{array}$ \\
\hline 13 & $\begin{array}{l}\text { Absalon } 3 \\
\text { (Ab3) }\end{array}$ & 900 & 50 & 60 & 1600 & 48 & 100 & 53720 & $\begin{array}{l}\text { Allophanic } \\
\text { soils } \\
\text { (Andosols) }\end{array}$ \\
\hline
\end{tabular}

\section{Methods}

The methodology used for this study is based on macroecology. The objective is to decipher the structural and functional dimensions of the vegetation. Using transects subdivided into quadrats and according to the minimum survey area (between 250 to 1050 m²; Table $1 \mathrm{~b}$ ) we generated data which are both average ecological and floristic descriptors (Fig. 5): species, numbers of individuals of populations of plant species [from regenerations to mature specimens (bio-demographic aspects)], diametric classes, classes of total heights and first branchings.

These features allowed us:

- - to assess the distribution of the sections of the individuals, the architecture of the formations, the characteristics of the canopies. 
- -to evaluate the phytomasses or biovolumes using the basal area (St) which corresponds to the sum of the areas of the circles that constitute the sections measured at 1.33 metres from the ground in accordance with international standards.

- - to find out the distribution of the species between the quadrats of the transects and between the stations using the Index of distribution which corresponds to the following formula: $\mathrm{Id}=\mathrm{fr} \times \mathrm{d}$ ( $\mathrm{fr}$ being the relative frequency and $\mathrm{d}(\mathrm{nb} / \mathrm{Sr}$ ) the density corresponding to the number of individuals of the species ( $\mathrm{nb}$ ) divided by the survey area ( $\mathrm{Sr}$, Table $1 \mathrm{~b})$.

- - to discover the relative dominance of ligneous plant species in relation to each other via the Index of Dominance (ID). ID = Id $\times$ St (basal area).

- - to conduct a Correspondence Factor Analysis (CFA) and an Ascending Hierarchical Classification (AHC) from the XLSTAT software (new version), which allowed us to compare the stations with one another with regard to the population structures of the different species.

- - to conduct an analysis of the species by means of clustering taking as a reference the fr (relative frequency) and Density [two features of the Id (Index of distribution)]. This clustering was done using the k-means algorithm (Hartigan and Wong 1979). Variables were normalised.

\section{Results}

\section{Taxonomic diversity of natural flora in regenerationunder Mahoganys plantation}

To highlight the diversity of the families, genera and species of the natural flora developing under the Mahoganys plantations we have produced tables with the representatives of the different taxonomic levels (Families, Genera, Species) in rows and the survey stations in columns. The presence and absence of the species in the inventory stations was indicated by the numbers 1 and 0 . This made it possible to produce cumulative histograms and curves. The following figures show the stational distribution of the families, genera and species. With 63 families, 113 genera and 117 species, the taxonomic richness of the flora regenerating under the Mahoganys plantations taken as a reference is quite significant. However, the distributions within the different stations differ. The following families are the most distributed and are characterised by a higher Relative Frequency (FR) (around 50\%, Fig. 6): Arecaceae, Boraginaceae, Burseraceae, Clusiaseae, Cytheaceae, Cyclanthaceae, Dichapetalaceae, Elaeocarpaceae, Heliconiaceae, Lauraceae, Magniolaceae, Melastomataceae, Meliaceae, Mimosaceae, Myrtaceae, Piperaceae, Poaceae, Rubiaceae, Sapotaceae, Simaroubaceae, Solanaceae, Sterculiaceae.

S1 : Gros-Morne 1/ S2 : Gros-Morne 2/ S3 : Montravail/ S4 : Sainte-Marie 1/ S5 : Sainte-Marie 2 /S6 : Absalon 1/ S7 : Absalon 2/ S8 : Absalon $3 /$ S9 : Fond Lahaye 1/ S10 : Fond Lahaye 2/ S11 : Laricher 1/ S12: Laricher 2/ S13: Trou matelot. FA: Absolute Frequency (presence = 1, absence = 0) / FR: Relative Frequency $[(\mathrm{FA} \div 13) \times 100]$.

The generic richness of the families is high with respect to the sampling that constitutes the thirteen inventory stations and the most represented genres (FR around 50\%) are twenty in number or 17.7\% (Fig. 7a and b): Aniba, Asplundia, Cestrum, Chimarrhis, Cyathea, Dacryodes, Eugenia, Heliconia, Miconia, Myrcia, Ocotea, Palicourea, Piper, Pouteria, Psychotria, Simaruba, Sloanea, Swietenia, Talauma, Tapura.

S1 : Gros-Morne 1/ S2 : Gros-Morne 2/ S3 : Montravail/ S4 : Sainte-Marie 1/ S5 : Sainte-Marie 2 /S6 : Absalon 1/ S7 : Absalon 2 / S8 : Absalon 3/ S9 : Fond Lahaye 1/ S10: Fond Lahaye 2/ S11 : Laricher 1/ S12 : Laricher 2/ S13: Trou matelot. FA: Absolute Frequency (presence = 1, absence = 0) / FR: Relative frequency $[(\mathrm{FA} \div 13) \times 100]$.

S1 : Gros-Morne 1/ S2 : Gros-Morne 2/ S3 : Montravail/ S4 : Sainte-Marie 1/ S5 : Sainte-Marie 2 /S6 : Absalon 1/ S7 : Absalon 2/ S8 : Absalon 3/ S9 : Fond Lahaye 1/ S10: Fond Lahaye 2/ S11: Laricher 1/ S12: Laricher 2/ S13: Trou matelot. FA: Absolute Frequency (presence $=1$, absence $=0) /$ FR: Relative Frequency $[(\mathrm{FA} \div 13) \times 100]$.

Specific diversity is also significant, but with respect to the study plots, a small number of species have a Relative Frequency (FR, Fig. 8 a \& $b$ ) of at least 50\% (16.24\%): Aniba bracteata, Asplundia rigida, Cestrum laurifolium, Chimarrhis cymosa, Clidemia umbrosa, Cordia sulcata, Cythea arborea, Cythea muricata, Dacryodes excelsa, Hiliconia caribaea, Miconia trichotoma, Myrcia fallax, Palicourea crocea, Piper dilatatum, Pouteria pallida, Simarouba amara, Swietenia macrophylla, Talauma dodecapetala, Tapura latifolia.

S1 : Gros-Morne 1/ S2 : Gros-Morne 2/ S3 : Montravail/ S4 : Sainte-Marie 1/ S5 : Sainte-Marie 2 /S6 : Absalon 1/ S7 : Absalon 2/ S8 : Absalon 3/ S9 : Fond Lahaye 1/ S10 : Fond Lahaye 2/ S11 : Laricher 1/ S12: Laricher 2/ S13: Trou matelot. FA: Absolute Frequency (presence = 1, absence = 0) / FR: Relative Frequency $[(\mathrm{FA} \div 13) \times 100]$.

S1 : Gros-Morne 1/ S2 : Gros-Morne 2/ S3 : Montravail/ S4 : Sainte-Marie 1/ S5 : Sainte-Marie 2 /S6 : Absalon 1/ S7 : Absalon 2/ S8 : Absalon 3/ S9 : Fond Lahaye 1/ S10: Fond Lahaye 2/ S11 : Laricher 1/ S12 : Laricher 2/ S13: Trou matelot. FA: Absolute Frequency (presence = 1, absence = 0) / FR: Relative Frequency $[(\mathrm{FA} \div 13) \times 100]$.

\section{Structural and architectural characteristics of the indigenous flora in regeneration under Mahoganys plantation}

\section{General structure of regenerations for all stations}


Under the plantation forests of the study stations, the set of the epigeic ligneous individuals with bush and tree potentiality presenting various morphogenetic phases mostly have, at $1.33 \mathrm{~cm}$ from the ground, section diameters of $2.5 \mathrm{~cm}$ (Fig. 9a). From the quantitative point of view, the reduction factor is 3.74 among the populations of autochthonous species of the $2.5 \mathrm{~cm}$ and $5 \mathrm{~cm}$ classes, while the reduction factors are 13.9 and 21.8 respectively among those of the $2.5 \mathrm{~cm}, 10 \mathrm{~cm}$ and $15 \mathrm{~cm}$ classes. As shown in Fig. $9 \mathrm{a}$, for classes with a diameter greater than $15 \mathrm{~cm}$ the number of stems is between 39 and 663 times lower than that of the $2.5 \mathrm{~cm}$ class. The same is true for heights and first branchings (Fig. $9 \mathrm{~b}$ ) where the quantitative differences are significant among the classes of heights and first branchings. The reduction factors between the $1-8 \mathrm{~m}$ height class and the $8-15 \mathrm{~m}, 15-25 \mathrm{~m}, 25-35 \mathrm{~m}, 35-45 \mathrm{~m}$ and $45-55 \mathrm{~m}$ height classes are $12,26.8,26.8,77$ and 4535 respectively (Fig. $9 \mathrm{~b}$ ). The process is similar concerning the first branchings of which the quantitative reduction factors among the 1-8 $\mathrm{m}$ class and the 8-15 $\mathrm{m}, 15-25 \mathrm{~m}, 25-35 \mathrm{~m}$ and $35-45 \mathrm{~m}$ classes are 4.6, 4.86, 26.4 and 121.6 (Fig. 9b).

\section{Specific biodemographic structures for all stations}

The specific demographics show significant variations both in terms of the numbers of all the diameter classes and in terms of the numbers of each diameter class (Fig. 10). Individuals $2.5 \mathrm{~cm}$ in diameter are the majority and involve a small percentage of species, in particular those whose number of stems is at least fifty: Aniba bracteata, Cestrum laurifolium, Myrcia fallax, Myrcia splendens, Palicourea crocea, Pimenta racemosa, Piper dilatatum, Pouteria multiflora, Psychotria mapourioides, Psychotria muscosa, Swietenia macrophylla, Talauma dodecapatala, Tapura latifolia, Trichilia septentrionalis. Therefore, the dominant species with total numbers greater than 100 individuals are marginal and are the following (Fig. 10): Aniba bracteata, Cestrum laurifolium, Chimarrhis cymosa, Myrcia fallax, Mycia splendens, Palicourea crocea, Pimenta racemosa, Piper dilatatum, Pouteria multiflora, Psychotria muscosa, Swietenia macrophylla, Swietenia aubrevilleana, Tapura latifolia, Trichilia septentrionalis. It should also be noted that certain autochthonous species such as Cecropia schreberiana, Coccoloba swartzii, Cyathea arborea, Dacryodes excelsa, Guatteria caribaea, Inga laurina, Sloanea dentata and Sloanea massoni have a small number of representatives in several diameter classes (Fig. 10).

The distribution of species populations with respect to height class seems to follow the same trends as that observed for diameter class. Indeed, the majority of individuals have a height of between $1 \mathrm{~m}$ and $8 \mathrm{~m}$ and correspond to a number of taxa, particularly those whose number of specimens is greater than 50 (Fig. 11). Chimarrhis cymosa, Cyathea arborea, Cyathea muricata, Dacryodes excelsa, Guatteria caribaea, Heliconia caribaea, Myrcia

fallax, Myrcia splendens, Pouteria pallida are the species which differ from those of the majority group considered with respect to the $2.5 \mathrm{~cm}$ diameter class with at least 50 individuals (Fig. 11). Logically, the majority of the first branchings are between $1 \mathrm{~m}$ and $8 \mathrm{~m}$ (Fig. 12). However, quantitatively low individuals of a few species have their first branchings in greater height classes (Fig. 12). There seems to be a fairly significant relationship between the life history of the species, in particular their morphogenetic development, and their populational significance relative to the classes of diameters, heights and first branchings.

Distribution and ecological dominance of species for all stations

The Index of distribution (Id) of the species vis-à-vis the thirteen floristic survey stations results from the product of their relative frequency (FR) and the density (d) of their individuals (see methods section). This Id is rather significant evidence of the mode of populational distribution of the various regenerating species with respect to the inventory areas and indicates types of sociability ranging from dispersed to gregarious. Figure 13 shows an interspecies variation of the three aforementioned indicators. There seems to be a certain alignment of the curves. The Relative Frequency (FR) curve indicates that the majority of species are on average present in $30 \%$ of the stations, i.e. around four. The taxa whose relative frequency is greater than $60 \%$ are the following: Aniba bracteata, Chimarrhis cymasa, Cestrum laurifolium, Cyathea arborea, Cyathea muricata Dacryodes excelsa, Miconia trichotoma, Myrcia fallax, Palicourea crocea, Piper dilatatum, Pouteria pallida, Simarouba amara, Talauma dodecapetala, Tapura latifolia. In general, apart from Tapura latifolia whose density of individuals is relatively higher, the density of regenerating populations is low or even very low for certain species (Fig. 13). This leads to Indices of distribution (Id) which are also low to very low. At the level of the thirteen inventory plots, the most distributed species with an Id greater than or equal to 0.015 are, in order of significance: Tapura latifolia, Odontonema nitidum, Myrcia fallax, Myrcia spledens, Palicourea crocea, Psychotria muscosa, Piper dilatatum, Pouteria multiflora, Trichilia septentrionalis (Fig. 13). Figure 14 shows, for all the stations, four clusters based on the presence of the species (FR) and the size of their population (density).

Despite the low distribution of species characterised by the Id, it was necessary to determine their ecological significance using the Index of Dominance (ID). The latter results from the product of the Basal Area which is the sum of the cross-sectional areas of the stems of trees and bushes of each species at $1.33 \mathrm{~m}$ and of the Id. Tapura latifolia, Chimarrhis cymosa and Dacryodes excelsa are, in order of significance, the three dominant species with respect to the set of survey stations (Fig. 15). Unlike Chimarrhis cymosa and Dacryodes excelsa where the Basal Area (ST) and Id are respectively 3.66-0.0115 and 2.93-0.007, Tapura latifolia has an ST of 0.84 and an ID of 0.06 . These aspects are related to the distribution of the diameter classes and therefore the age classes for each species.

Figure 14 Socio-biological differentiations of the species (See Annex 1)

Figure 15 Specific variation of the basal area, the index of distribution and the index of dominance (trees and bushes). Multifactorial analyses 
The Correspondence Factor Analysis (CFA) based on a contingency table composed of 136 rows (species) and 13 columns (inventory stations) shows that there is a link between the rows and the columns since the p-value (0.0001) calculated is below the alpha significance level (0.05). Axes $\mathrm{F} 1$ and $\mathrm{F} 2$ (Inertia: $38.70 \%$ ) of Fig. 16a distinguish between stations both from a bioclimatic point of view and from a taxonomic point of view: stations with humid bioclimates [SM1, SM2, GM1, GM2, La1, La2, Ab1, Ab2, Ab3, TM, MT (Table 1)]; stations with subhumid bioclimates [FL1, FL2 (Table 1)]. The different groups of species are affine to the following ecosystemic potentialities (Fig. 16b): tropical sub-montane ombrophilous forest (Group A), tropical ombro-evergreen forest (Group D), tropical evergreen forest [Group B (Sloping area) and Group C (Riparian terrace)]. The distances between the species segregated by the first two factorial axes correspond to various degrees of similarity of their biodemographic structures. Within groups $A, B, C$ and D, the Relative Frequencies (FR) and the densities (d) of the species are appreciably similar while between these groups the specific differences (of the taxa) with regard to these indicators (FR and d) are pronounced.

Box 1

\section{Group A}

Pul (Psychotria uliginosa), Ha (Hedyosmum arborescens), Mm (Miconia mirabilis), Bp (Beilschmiedia pendula), Al (Aiphanes luciana ?), So (Swietenia mahagoni), Se (Sterculia caribaea), Dg (Drypetes glauca), Mt (Miconia trichotoma), Ps (Piper dussii), Ph (Piper hispidum), Om (Ocotea membranacea), Cum (Clidemia umbrosa), Pmu (Pouteria multiflora), Pre (Prestoea montana), Pta (Plinia pinnata), Mu (Marcgravia umbellata), Py (Psychotria berteriana), Sc (Sapium caribaeum), Mr (Marila racemosa), Ta (Trichilia pallida), Pse (Pouteria semecarpifolia), Sd (Sloanea dentata), Td (Talauma dodecapetala), Ppa (Pouteria pallida), Pd (Piper aduncum), My (Micropholis guyanensis), Lt (Licania ternatensis), Ts (Trichilia septentrionalis), TI (Tapura latifolia), Si (Sloanea dussii), Hb (Heliconia bihai), Ssp (Sloanea sp), Op (Ocotea patens), Eo (Eugenia oerstedeana), Pe (Piper aequale), Ed (Eugenia duchassaingiana), Cir (Conostegia icosandra), Et (Eugenia trinervia), BI (Besleria luthea), Sm (Sloanea massoni), Ce (Cecropia schreberiana), Chy (Chimarrhis cymosa), Cel (Cestrum laurifolium), Av (Artocarpus altilis var. non seminifera), Xm (Xylosma martinicensis),Cea (Cyathea arborea) Cte (Cyathea tenera), By (Bunchosia polystachia), Am (Aiphanes minima), Gsp (Guarea sp), Gk (Guarea kunthiana), Cls (Cordia sulcata), Cca (Cyathea muricata), Mc (Macfadyena unguis cati), Pm (Piper dilatatum), De (Dacryodes excelsa), Ab (Aniba bracteata), Tp (Tovomita plumieri), Sa (Simarouba amara), He (Heisteria coccinea), Dm (Dalbergia monetaria), Hsp (Heliconia sp), Caf (Costus afer), Cmh (Clidemia hirta), Ag (Asplundia insignis), Bv (Bambusa vulgaris), Ghu (Gonzalagunia hirsuta), Gc (Guatteria caribaea), Sw (Swietenia aubrevilleana), If (Ixora ferrea), Ol (Ocotea leucoxylon)/

\section{Group B}

Mla (Myrcia leptoclada), Co (Cedrela odorata), Md (Myrcia deflexa), Pcu (Piper reticulatum), Ciu (Croton corylifolius), Gh (Garcinia humilis), Bu (Bursera simaruba), Cf (Coffea liberica), On (Odontonema nitidum), Gt (Guazuma tomentosa), Pa (Piper amalago), Hi (Heliconia caribaea), Oc (Ocotea coriacea), Cb (Capparis baducca), Qt (Quararibea turbinata), Pmi (Psychotria microdon), Chr (Chrysophyllum argenteum), Fo (Faramea occidentalis), Asp (Aiphanes sp), Ba (Brosimum alicastrum), Ep (Eugenia pseudopsidium), Pma (Psychotria mapourioides)/

\section{Group C}

Ai (Andira inermis), Mss (Myrcia splendens), Pc (Palicourea crocea), Fe (Funtumia elastica), Wy (Swietenia macrophylla), Chio (Chionanthus compacta), Ra (Randia aculeata), Eh (Erythroxylon havanense), Em (Eugenia monticola), Bs (Bourreria succulenta), Bm (Bambusa multiplex), Pne (Psychotria nervosa), Lp (Lonchocarpus punctatus), Mia (Myrcia citrifolia), Pk (Petrea kohautiana), Ac (Acacia retusa), Mb (Manilkara bidentata), Pr (Pimenta racemosa), Cc (Callophyllum calaba), Mi (Mangifera indica), Cba (Chiococca alba), Csw (Coccoloba swartzii), Hc (Haematoxylon campechianum), Ea (Eugenia albicans), Fc (Ficus citrifolia), Lh (Lonchocarpus heptaphyllus), MI (Maytenus laevigata), II (Inga laurina), Cd (Casearia decandra) /

\section{Group D}

li (Inga ingoides), Psa (Psychotria muscosa), Tc (Tabernaemontana citrifolia), Mf (Myrcia fallax), Oe (Ocotea eggersiana), Pf (Pisonia fragrans), Vd (Vitex divaricata), In (Ilex nitida), Ga (Genipa americana), $\mathrm{Cg}$ (Cassipourea guianensis), Mg (Maytenus guianensis).

$\mathrm{Pp}$ (Picramnia pentandra) is a species common to stations Fl2 and La-2 / Cly (Conostegia calyptatra) is a species in regeneration common to stations G-M2, Ab3 and Fl2

The FL1, FL2 and Mt stations differ from the others from a floristic point of view, and so we have removed them from the contingency table. A new Correspondence Factor Analysis concerning only the stations influenced by the humid bioclimate (Group A, Fig. 16a) was carried out based on the new contingency table of 89 rows (Species) and 10 columns (Stations). The different positions of these humid stations on the plane defined by the first two factorial axes of Fig. 17a are related to their corteges of species in regeneration. It seems that each station is characterised by a phytocenosis of which certain taxa are highly specific. In reality, the degrees of taxonomic difference correspond to more or less significant distances between the stations presented on the plane formed by the factorial axes F1 and F2 (Fig. 17a). As for the variations in distance between taxa (Fig. 17b), they result from their differences in populational structures. These are related to the minimum survey areas (Table 1). The combinations of species (I, II, III, IV, V, Fig. 17b) which distinguish the study stations are just particular phytocenotic expressions of the tropical ombro-evergreen and submontane ombrophilous forest vegetation. 
Figure 17 Biodemographic differentiation [a: Stational, b: Specific (Box 2)]

Box 2

\section{Group I}

Pae (Piper aequale), Hr (Heliconia caribaea), Ep (Eugenia pseudopsidium), Bv (Bambusa vulgaris), Fo (Faramea occidentalis), Caf (Costus afer), Ssp (Sloanea sp), Eo (Eugenia oerstedeana), Hn (Heisteria coccinea), Hp (Heliconia sp), Chi (Clidemia hirta), An (Asplundia insignis), Td (Talauma dodecapetala), Op (Ocotea patens), Coy (Conostegia calyptatra), Pyc (Psychotria muscosa), Pys (Psychotria mapourioides), Gh (Garcinia humilis), Gc (Guatteria caribaea), Cym (Cyathea muricata), Ab (Aniba bracteata), Lt (Licania ternatensis), If (Ixora ferrea), TI (Tapura latifolia), Ts (Trichilia septentrionalis), li (Inga ingoides).

\section{Group II}

Pa (Piper aduncum,) Hb (Heliconia bihai), Mx (Myrcia fallax), Si (Sloanea dussii), My (Micropholis guyanensis), Sy (Swietenia macrophylla), Ppa (Pouteria pallida), Qt (Quararibea turbinata), Dm (Dalbergia monetaria), Pf (Pisonia fragrans), Pyt (Psychotria microdon)

\section{Group III}

Phi (Piper hispidum), Bu (Bunchosia polystachia), Sc (Sapium caribaeum), Dg (Drypetes glauca), Gs (Guarea sp), Mu (Marcgravia umbellata), Xm (Xylosma martinicensis), II (Inga laurina), BI (Besleria luthea), Sm (Sloanea massoni), Cs (Cecropia schreberiana), Aa (Artocarpus altilis var. non seminifera), Pt (Picramnia pentandra), Tp (Tovomita plumieri), Sw (Swietenia aubrevilleana), Pdi (Piper dilatatum), Et (Eugenia trinervia), Pdu (Piper dussii), Pli (Plinia pinnata), Mt (Miconia trichotoma), Mm (Miconia mirabilis), Sa (Simarouba amara), Oe (Ocotea eggersiana), Pc (Palicourea crocea), Eg (Eugenia duchassaingiana), Cic (Conostegia icosandra), Cl (Cestrum laurifolium), Pyb (Psychotria berteriana), Pyu (Psychotria uliginosa), Cya (Cyathea arborea), Se (Sterculia caribaea), Cum (Clidemia umbrosa), Csu (Cordia sulcata), Gk (Guarea kunthiana), Al (Aiphanes luciana), Bp (Beilschmiedia pendula), Ol (Ocotea leucoxylon), Ha (Hedyosmum arborescens), Sh (Swietenia mahagoni)

\section{Group IV}

Mr (Marila racemosa), Da (Dacryodes excelsa), Cyt (Cyathea tenera), Om (Ocotea membranacea), Mc (Macfadyena unguis cati), Cy (Chimarrhis cymosa), Am (Aiphanes minima), Pam (Piper amalago), Ptn (Prestoea montana)

\section{Group V}

Pou (Pouteria multiflora), Pse (Pouteria semecarpifolia)

St (Sloanea dentata) is a regenerating species common to stations SM1, Ab2 and La1

Two Ascending Hierarchical Classifications (AHC) based on general similarity were carried out based on the set of the stations (13) and their species (136) highlighting many distinguishing features both between stations and between species. First, the set of the stations have a similarity of 0.434 . Two groups of stations subject to the spatiotemporal dynamics of humid (group A) and humid subhumid (group B) bioclimates stand out (Fig. 18). They are each subdivided into two subgroups $(A 1, A 2)$ and $(B 1, B 2)$ whose similarity is $0.58(A 1, A 2)$ and $0.53(B 1, B 2)$. The stations in subgroup $A 1$ present various degrees of similarity ranging on average from 0.67 to 0.82 . This process is identical for stations in subgroup $A 2$, except that the degrees of similarity are lower (Fig. 18). Overall the degrees of similarity between the stations of group B are lower than those of group A. The ecosystemic differentiations are clearly explained in Fig. 18 and the stations with the most similarity are Sainte Marie 1 and 2. Second, the Ascending Hierarchical Classification carried out based on the populational structures of the species segregate three groups (I, II, III) which are completely separated and therefore have no similarity (similarity index equal to zero). Species in groups I and II have just about average to very low similarity in population structure between 0.075 and 0.46 (Fig. 19). Group III, made up of two subgroups (IIla and IIlb), includes the majority of the species whose degrees of populational similarity vary from 0.075 (IIla: a single species) to 1 (Fig. 19). Figure 19 shows a series of subdivisions, from the lowest value (0.0745) to the maximum value (1) of the index of similarity. This is related to the stational quantitative stational significance of the species.

Subgroup IIIb is a suitable example of this. Its subdivisions, in particular IIlb2 and IIlb3, branch out into numerous units: Illb2 [similarity index of 0.3 (all species in the subgroup) to 1] and IIIb3 [similarity index of 0.3 (all species in the subgroup) to 0.93 ]. Species with similarity indices between 0.85 and 1 have a high degree of biodemographic similarity and form quantitatively variable corteges. The corteges of species whose similarity is between 0.925 and 1 are all separated.

\section{Discussion}

\section{Taxonomic richness of the natural flora in regeneration under Mahoganys plantation}

Under the physical constraint of the fields of trees that constitute the mature Mahoganys plantations of the inventory stations in humid and humid sub-humid bioclimates, the families to which the inventoried species belong correspond to singular floristic expressions. Indeed, if a larger number of stations had been considered in this study, other families could have been counted. The most frequent genera [FR $\geq 50 \%$, Fig. 7] are typical of the sub- 
montane ombrophilous and seasonal ombro-evergreen floristic formations. The same is true for the species with respect to the bioclimates and types of vegetation mentioned above, except that the latter are associated with different stages of phytocenotic succession (Fig. 22). Table 2 shows the most frequent species in regeneration [FR FR $\geq 50 \%$ ] (See Annexes 1 and 2).

Table 2

The species presenting the most significant populations with respect to the thirteen stations

\begin{tabular}{|c|c|c|}
\hline Species & $\begin{array}{l}\text { Physiognomic } \\
\text { types }\end{array}$ & Preferential dynamic stages (Fig. 22) \\
\hline Aniba bracteata & Tree & Late, pre-climactic and climactic forest stages \\
\hline Asplundia rigida & Herbaceous liana & Pre-climactic and climactic forest stages \\
\hline Cestrum laurifolium & Bush to small tree & Secondary forest stages and large gaps in late and pre-climactic forests \\
\hline Chimarrhis cymosa & Tree & Late, pre-climactic and climactic riparian forest stages \\
\hline Clidemia umbrosa & Bush & Bush and pre-forest stages, very large forest gaps \\
\hline Cordia sulcata & Tree & Pre-forest, secondary forest stages and gaps in late and pre-climactic forests \\
\hline Cythea arborea & False tree & Large gaps in secondary forests, pre-climactic and climactic, Areas in perpetual rejuvenation \\
\hline Cythea muricata & False tree & Late, pre-climactic and climactic secondary forest stages \\
\hline Dacryodes excelsa & Tree & Late, pre-climactic and climactic secondary forest stages \\
\hline Hiliconia caribaea & Large herbaceous & $\begin{array}{l}\text { Affines of large gaps in secondary forests, pre-climactic and climactic, Areas in perpetual } \\
\text { rejuvenation }\end{array}$ \\
\hline Miconia trichotoma & Small tree & Large gaps in secondary forests, pre-climactic and climactic \\
\hline Myrcia fallax & Tree & Secondary forest stages and large gaps in late and pre-climactic forests \\
\hline Palicourea crocea & Bush & Large gaps in secondary forests, pre-climactic \\
\hline Piper dilatatum & Bush & Large gaps in secondary forests, pre-climactic \\
\hline Pouteria pallida & Tree & Late, pre-climactic and climactic forest stages \\
\hline Simarouba amara & Tree & Small gaps in late-stage, pre-climactic and climactic forests \\
\hline $\begin{array}{l}\text { Talauma } \\
\text { dodecapetala }\end{array}$ & Tree & Late, pre-climactic and climactic forest stages \\
\hline Tapura latifolia & Tree & Late, pre-climactic and climactic forest stages \\
\hline
\end{tabular}

\section{Lateral and vertical structure (architecture) of species populations (All stations)}

The classes of diameters and heights (total heights and first branchings) show a concentration of individuals in very low values, $2.5 \mathrm{~cm}-5 \mathrm{~cm}$ and $1 \mathrm{~m}-8 \mathrm{~m}$ respectively. This relates to the fact that the majority of individuals from the taxa which regenerate under the plantations of Mahoganys of the inventory stations are in the phase of morphogenetic expansion. In other words, they are in the early stages of their morphological development. Regardless of the quantitative aspect, the meticulous analysis of the distribution of specific numbers by diameter and height class is congruent with the elements indicated above: the diameter classes $2.5 \mathrm{~cm}$ and $5 \mathrm{~cm}$ as well as the height classes (total and first branchings) between $1 \mathrm{~m}$ and $8 \mathrm{~m}$ are the most represented. However, a small number of taxa differ due to their horizontal and vertical structures in which are represented few individuals in the classes of diameters greater than $25 \mathrm{~cm}$ as well as in classes of total heights and first branchings greater than $15 \mathrm{~m}$. To explain this, several factors informed by our long experience as floristic inventorists are possible. Although they have different morphogenetic characteristics (in particular diameters and heights of mature specimens), the items of large biomasses with sections between $60 \mathrm{~cm}$ and $120 \mathrm{~cm}$ and heights greater than $25 \mathrm{~m}$ were composed of old natural forest phytocenoses (Figs. 20, 11 and 12). It is highly plausible that these relictual trees were structuring elements of the upper strata of these phytocenoses of the past. For unexplained reasons, the latter avoided the deforestation preceding the monotypic plantation of Mohoganys fields. Either these trees were at the edge of the planted plots or the deforestation was selective for the benefit of construction, carpentry and woodworking activities. Trees with sections between $20 \mathrm{~cm}$ and $55 \mathrm{~cm}$ and heights less than $25 \mathrm{~m}$ are either mature (regardless of what strata they belong to) or are at different stages of morphogenetic development (Figs. 21, 11 and 12).

\section{Ecological significance of the species (all stations)}

The index of distribution used in this study is a global index since the relative frequency (FR) and density (d) are global indicators relative to the set of stations. This index of distribution (Id) is highly variable and results from the covariant viability of the Relative Frequency (FR) of the species and the density (d) of their individuals (Fig. 13). Indeed, the number of individuals varies both between the quadrats of the transects making up the survey stations and between the latter (the transects). Generally speaking, species in regeneration have a cumulative density of individuals (for the thirteen stations) which is low or very low, although this seems to be strongly correlated with the relative frequency (Fig. 13). Within each inventory transect 
(station), the absolute frequency or number of species occurrences with respect to the quadrats varies as well as their populations. This process is similar between stations. The most widely distributed species correspond to those whose FR $\geq 69$ and d $\geq 0.005$ (Fig. 13): Aniba bracteata, Cestrum laurifolium, Chimarrhis cymosa, Cythea arborea, Cyathea muricata, Dacryodes excelsa, Miconia trichotoma, Myrcia Fallax, Palicourea crocea, Piper dilatatum, Pouteria pallida, Talauma dodecaprtala, Tapura latifolia. The preceding factors show that the species in regeneration under the plantations of Mahoganys are little distributed. This is linked with their methods of clustering or "socialisation" ranging from dispersed to gregarious and the highly differentiated quantitative significance of their populations. The reasons for this appear to originate from the strategies of dissemination of seeds or diaspores. For the dispersal of their seeds and in a proportional manner, the regenerating species favour zoochory (notably ornithochory) and barochory. However, in the case of trees which are among the most numerous physiognomic types, barochory conditions higher densities of gregarious populations when the following two categories of autochthonous seeders are present: relictual trees with low growth found within or at the edge of Mahoganys plantations which belonged to ancient natural forest groupings, and adult trees with average or fast growth which underwent their morphogenetic development within the Mahoganys plantations.

As the results of the Correspondence Factorial Analyses (CFA) and of the Ascending Hierarchical Classifications (AHC) show, the mesological factors and the dissemination vectors as well as the phenological methods of the seeders adjoining the stations are determining factors which condition the structure of populations of regenerating species. These are affine of humid, humid subhumid and dry subhumid bioclimates and consist of submontane ombrophilous, seasonal ombro-evergreen and seasonal evergreen phytocenoses respectively. When the individuals of the taxa are small in number and distributed in a large number of stations, one may think that ornithochore dissemination is the most effective. However, when there are a large number of individuals and they are distributed in a low number of stations, the predominance of barochory seems to be the most plausible explanation. On the other hand, there may be situations where the species have low relative frequencies with sparse populations. In the latter case, it is very likely that these species are largely barochoric and have phenological peculiarities resulting in infructescences with little fruit. The phase difference between the external environment (macroclimate) and the internal environment of these "Mahogany plantation" biosystems due to a very simplified stratification would be in covariance with multiple sites of installation and expansion of fairly specific factorial characteristics. Indeed, in these forests which one could call "fields of planted trees" the very simplified stratification is composed of a dominant upper stratum of adult Mahoganys, a middle stratum formed of scattered individuals (therefore sparse) of expanding morphogenetic Mahoganys and mature autochthonous trees. This state of affairs, associated with the deficiency of the disseminating vector fauna, could constitute a clue that would explain the low population densities of the vast majority of the species.

\section{Conclusion}

Despite their non-contiguous crowns forming a sparse canopy, the plantations of Mahoganys, due to the geometrical constraints which they impose, enable the colonisation of species of natural flora. The floristic differences observed between the inventory stations largely depend on the seed dispersal processes and the structure of the mesological factors. Among these are the stational bioclimates, the declivity of the grounds and the types of edaphic systems. There are also other parameters such as the quantitative significance of the seeders adjoining the planted plots and the frequency of flooding and exposure of low-lying riparian terraces. Regenerating species present a broad taxonomic spectrum and belong to stages of the plant dynamic ranging from pioneer stages to climactic stages through to post-pioneer stages (Fig. 22). The fact that the species of advanced phases (pre-climactic and climactic) regenerate under mature plantations of Mahoganys constitutes a shunt to the dynamics of the vegetation. Indeed, species such as Aniba bracteata, Guatteria caribaea, Chimarrhis cymosa, Dacryodes excelsa, Pouteria multiflora, Pouteria pallida, Sloanea dendata, Sloanea dussii, Sloanea massoni, Talauma dodecapetala and Tapura latifolia are predominantly matrix species of mature pre-climactic and climactic forest groupings of humid and humid subhumid bioclimates. Pimenta racemosa is a dominant taxon [high distribution (Id) and high overall basal area] of the advanced phases of the phytocenotic succession of pre-climactic and climactic forest formations influenced by the dry subhumid bioclimate. The other taxa listed are characteristic of various types of sylvatic gaps and severely degraded forests which are called regressive (young and secondary forests, see Annex 2). Rather pertinently, this study shows that the Mahoganys plantations can be used as ecological engineering tools to activate plant dynamics, particularly in highly diminished or unstructured environments with humid, humid subhumid and dry subhumid bioclimates. Anthropisation, as well as the frequent cyclonic hazards, leads to a regression from the forest stage to the herbaceous, bush or mixed stage of the advanced, pre-climactic and climactic plant ecosystems. In this respect, the requirements of forestry, in particular to facilitate the cutting and extraction of logs (trunks), should not be imposed as regards the distances between the specimens of the old Mahoganys plantations, which are too great. This results in a phase difference between the macroclimate and the intra-plantation climate which can be medium to low depending on the level of overall morphogenetic development of the individuals. The dense plantation of Mahoganys would be the most logical solution because at the end of the growth of individuals, shorter exclusion distances between them lead to an interior environment that is climatically much more dephased climatically. In general, this study shows that mature plantations of not very competitive introduced forest species can greatly accelerate phytocenotic succession and increase specific richness. (Richards et al. 2010; Bremer and Farley 2010; de Jong 2010; Paquette and Messier 2010; Verheyen et al. 2016; Aide et al. 2013).

\section{Declarations}

\section{Ethics approval and consent to participate}

Not applicable. 


\section{Consent for publication}

Not applicable.

\section{Availability of data and material}

Please contact author for data request.

\section{Competing interests}

The author declares he has no competing interests.

\section{Funding}

Not applicable.

\section{Authors' contributions}

All the authors in a proportional way participated in the construction of the methodology, in the data collection and their processing as well as in the writing. PJ proposed the protocol for floristic surveys which was discussed in a community manner. PJ, KB, J-PC, YA, S E-M, SS and Y J-F carried out the floristic surveys and formatted the data. The data processing and their interpretations were carried out mainly by PJ. J-E S carried out from all the surveys a statistical analysis to decipher clusters. J-V M and PM participated in all phases of the drafting.

\section{Acknowledgements}

Our thanks go first to the members of the Antilles "BIORECA" group from the "UMR ESPACE DEV" laboratory and secondly to the CTM (Local Authority of Martinique) and the University of the Antilles which annually fund our research programmes.

\section{References}

1. Aide TM, Clark ML, Grau HR, López-Carr D, Levy MA, Redo D, ... \& Muñiz M (2013) Deforestation and Reforestation of L atin A merica and the C aribbean (2001-2010). Biotropica45(2) 262-271.

2. Arets EJMM, Van der Meer PJ, Verwer CC, Hengeveld GM, Tolkamp GW, Nabuurs GJ, \& Van Oorschot M (2011) Global wood production: assessment of industrial round wood supply from forest management systems in different global regions(No. 1808). Alterra, Wageningen-UR.

3. Baillard K (2016) The effects of anthropization on the coastal island vegetation: the example of the mangrove forest of the Bay of Fort-de-France (Martinique). International Journal of Recent Research and Review9(2) 1-14.

4. Banin L, Lewis, SL, Lopez-Gonzalez G, Baker TR, Quesada CA, Chao KJ, ... \& Tan S (2014) Tropical forest wood production: a cross-continental comparison. Journal of Ecology102(4) 1025-1037.

5. Bar-Yosef O (2017) Multiple origins of agriculture in Eurasia and Africa. In On human nature(pp.297-331). Academic

6. Borrell F, Junno A and Barceló JA (2015) Synchronous environmental and cultural change in the emergence of agricultural economies 10,000 years ago in the Levant. PloS one10(8).

7. Bremer LL and Farley KA (2010) La foresterie de plantation rétablit-elle la biodiversité ou crée-t-elle des déserts verts? Une synthèse des effets des transitions d'utilisation des terres sur la richesse en espèces végétales. Biodiversité et conservation 19(14) 3893-3915.

8. Brown N, Jennings S and Clements T (2003) The ecology, silviculture and biogeography of mahogany (Swietenia macrophylla): a critical review of the evidence. Perspectives in plant ecology, evolution and systematics6(1-2) 37-49.

9. Cano Ortiz A, Musarella CM, Piñar Fuentes J C, Bartolomé Esteban C, Quinto-Canas R, Pinto Gomes CJ, ... \& Cano E (2018) Advances in the Knowledge of the Vegetation of Hispaniola (Caribbean Central America). London: InthechOpen 83-99.

10. Castañeda-Posadas C and Cevallos-Ferriz SR (2007) Swietenia (Meliaceae) flower in Late Oligocene-Early Miocene amber from Simojovel de Allende, Chiapas, Mexico. American Journal of Botany 94(11) 1821-1827.

11. Castilla-Beltrán A, de Nascimento L, Fernández-Palacios JM, Fonville T, Whittaker RJ, Edwards M and Nogué S (2019) Late Holocene environmental change and the anthropization of the highlands of Santo Antão Island, Cabo Verde. Palaeogeography, palaeoclimatology, palaeoecology524 101-117.

12. Chaudhary A, Carrasco LR and Kastner, T (2017) Linking national wood consumption with global biodiversity and ecosystem service losses. Science of The Total Environment586 985-994.

13. Clement CR, Cristo-Araújo D, Coppens D’Eeckenbrugge G, Alves Pereira A, and Picanço-Rodrigues D (2010) Origin and domestication of native Amazonian crops. Diversity2(1) 72-106.

14. Colunga-GarcíaMarín P and Zizumbo-Villarreal D (2004) Domestication of plants in Maya lowlands. Economic Botany 58(1) 101-110.

15. Costa $\mathrm{CH}$, Audin L and Benavente C (2009) Geomorphology as a tool for analysis of seismogenic sources in Latin America and the Caribbean. Developments in Earth Surface Processes13 29-47.

Page $12 / 25$ 
16. Crawford GW (2006) East Asian plant domestication. archaeology of asia 77-95.

17. de Jong W (2010) Forest rehabilitation and its implication for forest transition theory. Biotropica 42(1) 3-9.

18. De la Barba Francis JK (1991) Swietenia mahagoni Jacq, West Indies Mahogany: Meliaceae, Mahogany family. US Department of Agriculture, Forest Service, Southern Forest Experiment Station, Institute of Tropical Forestry, Antilles. Journal of Biogeography 347-363.

19. DeFries RS, Rudel T, Uriarte M and Hansen M (2010) Deforestation driven by urban population growth and agricultural trade in the twenty-first century. Nature Geoscience3(3) 178-181.

20. DeWalt SJ, Ickes K and James A (2016) Forest and community structure of tropical sub-montane rain forests on the island of Dominica, Lesser Antilles. Caribbean Naturalist (1) 116-137.

21. Erickson DL, Smith BD, Clarke AC, Sandweiss DH \& Tuross N (2005) An Asian origin for a 10,000-year-old domesticated plant in the Americas. Proceedings of the National Academy of Sciences102(51) 18315-18320.

22. Evans J (1992) Plantation forestry in the tropics: tree planting for industrial, social, environmental, and agroforestry purposes. Oxford University Press.

23. Evans J and Turnbull JW (2004) Plantation forestry in the tropics: The role, silviculture, and use of planted forests for industrial, social, environmental, and agroforestry purposes(No. 3. ed.). Oxford University Press.

24. Francis JK and Lowe CA (2000) Silvics of Native and Exotic Trees of Puerto Rico and the Caribbean Islands (Spanish version). General Technical Report IITF-GTR-15 US Department of Agriculture, Forest Service International Institute of Tropical Forestry.

25. Fredericksen TS and Putz FE (2003) Intensification sylvicole pour la conservation des forêts tropicales. Biodiversité et conservation12 (7) 14451453.

26. Fritz S, See L, McCallum I, You L, Bun A, Moltchanova E ... \& Havlik P (2015) Mapping global cropland and field size. Global change biology 21(5) 1980-1992.

27. Furukawa, Kayo, C., Kadoya, T., Kastner, T., Hondo, H., Matsuda, H., \& Kaneko, N. (2015). Forest harvest index: Accounting for global gross forest cover loss of wood production and an application of trade analysis. Global Ecology and Conservation, 4, 150-159.

28. Garmon WT, Allen CD and Groom KM (2017) Geologic and tectonic background of the Lesser Antilles. In Landscapes and Landforms of the Lesser Antilles(pp. 7-15). Springer, Cham.

29. Gastó J, Subercaseaux D and Vera L (2012) Ecology: an integrated science for the artificialization of nature. Ciencia e Investigación Agraria39(3) 397-410.

30. Gignoux CR, Henn BM and Mountain JL (2011) Rapid, global demographic expansions after the origins of agriculture. Proceedings of the National Academy of Sciences108(15) 6044-6049.

31. Gleason HA and Panshin AJ (1936) Swietenia Krukovii: a new species of mahogany from Brazil. American Journal of Botany 23(1) 21-26.

32. Gremillion KJ (Ed.) (1997) People, plants, and landscapes: Studies in paleoethnobotany. University of Alabama Press.

33. Gupta AK (2004) Origin of agriculture and domestication of plants and animals linked to early Holocene climate amelioration. Current scienceBangalore87 54-59.

34. Haggar JP, Briscoe CB and Butterfield RP (1998) Native species: a resource for the diversification of forestry production in the lowland humid tropics. Forest Ecology and Management106(2-3) 195-203.

35. Hartigan JA and Wong MA (1979) Algorithm AS 136: A K-means clustering algorithm. Applied Statistics 28 100-108.

36. Hawkes JG, Maxted N and Ford-Lloyd BV (2000) Evolution of plants under domestication. In The Ex Situ Conservation of Plant Genetic Resources(pp. 19-31). Springer, Dordrecht.

37. Howard FW (1995) Reduction of damage to mahogany by mahogany shoot borer and mahogany leaf miner by use of azadirachtin. Journal of Tropical Forest Science 454-461.

38. Howard RA (1962) Volcanisme et végétation dans les Petites Antilles. Journal de l'Arnold Arboretum43 (3) 279 -314.

39. Huguet L and Marie E (1951) Les plantations d'Acajou d'Amérique des Antilles françaises. Bois \& forets des tropiques17(17) 12-25.

40. Ivantsova E, Krylov P, Novochadov V, Onistratenko N and Matveeva A (2020) Components of Anthropogenically Transformed Landscapes of South of Russia Interaction. In IV International Scientific and Practical Conference'Anthropogenic Transformation of Geospace: Nature, Economy, Society (ATG 2019)

41. Jain RK and Singh B (1999) Fuelwood characteristics of selected indigenous tree species from central India. Bioresource Technology68(3) 305308.

42. Krishna and Maurya H (2018) A Review on Favorable Approaches of Swietenia macrophylla Plant for the Human Ailments. Indian Journal of Pharmaceutical and Biological Research6(03), 60-65.

43. Krisnawati $\mathrm{H}$, Kallio MH and Kanninen M (2011) Swietenia macrophylla King: ecology, silviculture and productivity. CIFOR.

44. Lamberg JA and Ojala J (2006) Evolution of competitive strategies in global forestry industries: Introduction. In The Evolution of Competitive Strategies in Global Forestry Industries(pp. 1-29). Springer, Dordrecht. 
45. Levis C, Costa FR, Bongers F, Peña-Claros M, Clement CR, Junqueira AB ... \& Castilho CV (2017) Persistent effects of pre-Columbian plant domestication on Amazonian forest composition. Science355(6328) 925-931.

46. Little EL, Woodbury RO and Wadsworth FH (1974) Trees of Puerto Rico and the Virgin islands(No. 449). US Department of Agriculture, Forest Service.

47. Mabberley DJ (1982) William roxburgh's 'botanical description of a new species of swietenia (Mahogany)'and other overlooked binomials in 36 vascular plant families. Taxon31(1) 65-73.

48. Mayhew JE, Andrew M, Sandom JH, Thayaparan S and Newton AC (2003) Silvicultural systems for big-leaf mahogany plantations. In Big-Leaf Mahogany(pp. 261-277). Springer, New York, NY. Anderson JL (2012) Mahogany Harvard University Press.

49. Meyfroidt P, Rudel TK and Lambin EF (2010) Forest transitions, trade, and the global displacement of land use. Proceedings of the National Academy of Sciences107(49) 20917-20922.

50. Nelson M, Silverstone S, Reiss KC, Vakil T and Robertson M (2011) Enriched secondary subtropical forest through line-planting for sustainable timber production in Puerto Rico. Bois et forêts des tropiques309 51-61.

51. Nishijima S, Furukawa T, Kadoya T, Ishihama F, Kastner T, Matsuda H and Kaneko N (2016) Evaluating the impacts of wood production and trade on bird extinction risks. Ecological indicators71 368-376.

52. Norghauer JM, Martin AR, Mycroft EE, James A and Thomas SC (2011) Island invasion by a threatened tree species: evidence for natural enemy release of mahogany (Swietenia macrophylla) on Dominica, Lesser Antilles. PLoS One6(4).

53. Olschewski R and Benítez PC (2010) Optimizing joint production of timber and carbon sequestration of afforestation projects. Journal of Forest Economics16(1) 1-10.

54. Pagán Jiménez JR (2011) Early phytocultural processes in the pre-colonial Antilles. Communities in contact: essays in archaeology, ethnohistory, and ethnography of the Amerindian circum-Caribbean. Leiden: Sidestone 87-116.

55. Pagán-Jiménez JR (2013) Human-plant dynamics in the precolonial Antilles. The Oxford handbook of Caribbean archaeology $391-406$.

56. Paquette A and Messier C (2010) The role of plantations in managing the world's forests in the Anthropocene. Frontiers in Ecology and the Environment8(1) 27-34.

57. Parker IM, López I, Petersen JJ, Anaya N, Cubilla-Rios L and Potter D (2010) Domestication syndrome in Caimito (Chrysophyllum cainito L.): fruit and seed characteristics. Economic botany 64(2), 161-175.

58. Montoya E, Lombardo U, Levis C, Aymard GA and Mayle FE (2020) Human contribution to Amazonian plant diversity: legacy of pre-Columbian land use in modern plant communities. In Neotropical Diversification: Patterns and Processes(pp. 495-520). Springer, Cham.

59. Purugganan MD and Fuller DQ (2009) The nature of selection during plant domestication. Nature457(7231) 843-848.

60. Quinton JN, Govers G, Van Oost K and Bardgett RD (2010) The impact of agricultural soil erosion on biogeochemical cycling. Nature Geoscience3(5), 311-314.

61. Reed CA (Ed.) (2011) Origins of agriculture. Walter de Gruyter.

62. Richards AE, Forrester DI, Bauhus J and Scherer-Lorenzen M (2010) The influence of mixed tree plantations on the nutrition of individual species: a review. Tree Physiology, 30(9), 1192-1208.

63. Sewerniak P (2016) Differences in early dynamics and effects of slope aspect between naturally regenerated and planted Pinus sylvestris woodland on inland dunes in Poland. iForest-Biogeosciences and Forestry, 9(6), 875.

64. Silantyeva MM, Elesova NV, Hensen I, Terekhina TA, Grebennikova AY and Ovcharova NV (2020) Influence of Agricultural Reclamation on Vegetation Cover and Biodiversity in the Forests and Steppes of Kulunda. In KULUNDA: Climate Smart Agriculture(pp. 143-154). Springer, Cham.

65. Simons AJ and Leakey RRB (2004) Tree domestication in tropical agroforestry. In New vistas in agroforestry(pp. 167-181). Springer, Dordrecht.

66. Smith BD (1997) The initial domestication of Cucurbita pepo in the Americas 10,000 years ago. Science276(5314) $932-934$.

67. Snook LK (1996) Catastrophic disturbance, logging and the ecology of mahogany (Swietenia macrophylla King): grounds for listing a major tropical timber species in CITES. Botanical Journal of the Linnean Society122(1) 35-46.

68. Stehlé H (1957) Les Mahoganys des Antilles françaises et le Swietenia Aubrevilleana Stehlé et Cusin, nov. spec.(25e contribution). Bulletin de la Société Botanique de France, 104(sup1), 41-51.

69. Terrell JE, Hart JP, Barut S, Cellinese N, Curet A, Denham T ... and Pohl ME (2003) Domesticated landscapes: The subsistence ecology of plant and animal domestication. Journal of Archaeological Method and Theory10(4) 323-368.

70. Triantis KA, Mylonas M, Lika K and Vardinoyannis K (2003) A model for the species-area-habitat relationship. Journal of Biogeography30(1) 1927.

71. Tubiello FN, Salvatore M, Ferrara AF, House J, Federici S, Rossi S ... and Prosperi P (2015) The contribution of agriculture, forestry and other land use activities to global warming, 1990-2012. Global change biology21(7) 2655-2660.

72. Verheyen K, Vanhellemont M, Auge H, Baeten L, Baraloto C, Barsoum N ... and Haase J (2016) Contributions of a global network of tree diversity experiments to sustainable forest plantations. Ambio 45(1) 29-41 
73. Walters BB and Hansen L (2013) Farmed landscapes, trees and forest conservation in Saint Lucia (West Indies). Environmental conservation40(3) 211-221.

74. Weaver PL, Valenta J and Officer PC (1985) Timber plantations and water resources on St. Vincent, West Indies. Watershed Managerment in the Caribbean.

75. Wingfield MJ, Coutinho TA, Roux J and Wingfield BD (2002) The future of exotic plantation forestry in the tropics and southern Hemisphere: Lessons from pitch canker. The Southern African Forestry Journal195(1) 79-82.

\section{Figures}

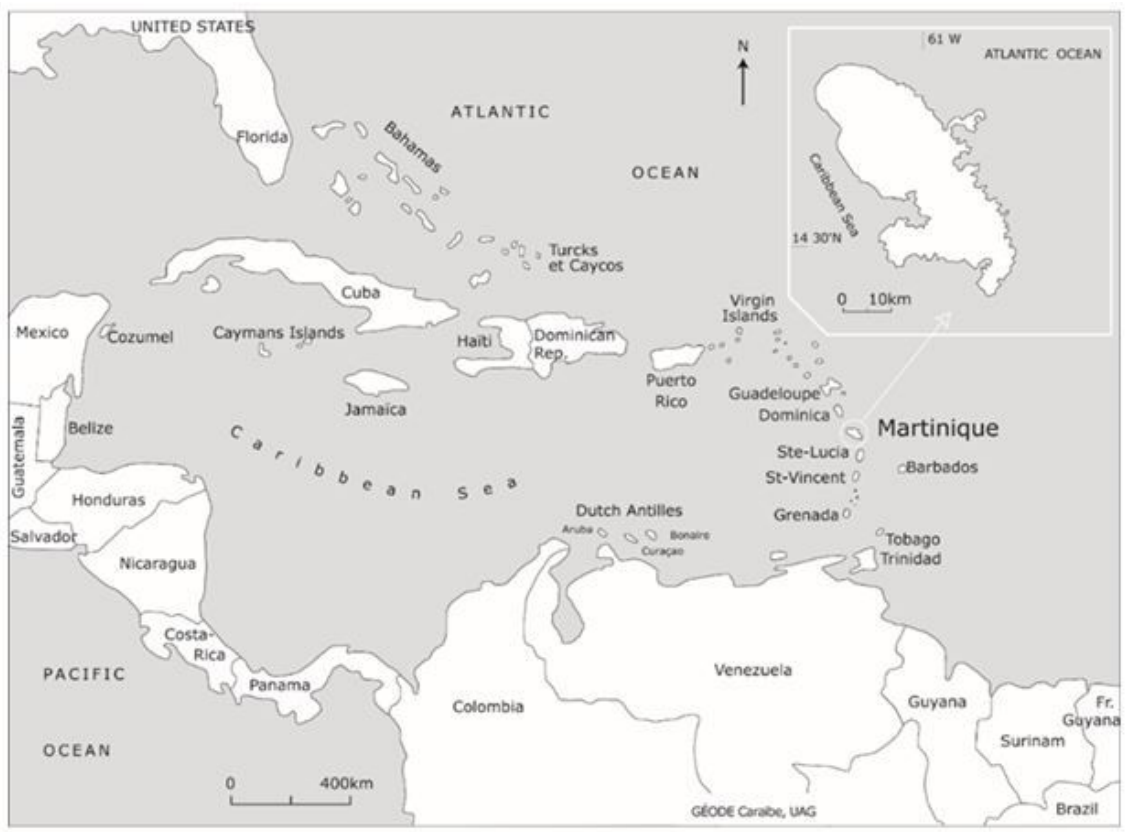

\section{Figure 1}

The Lesser Antilles in the Caribbean.

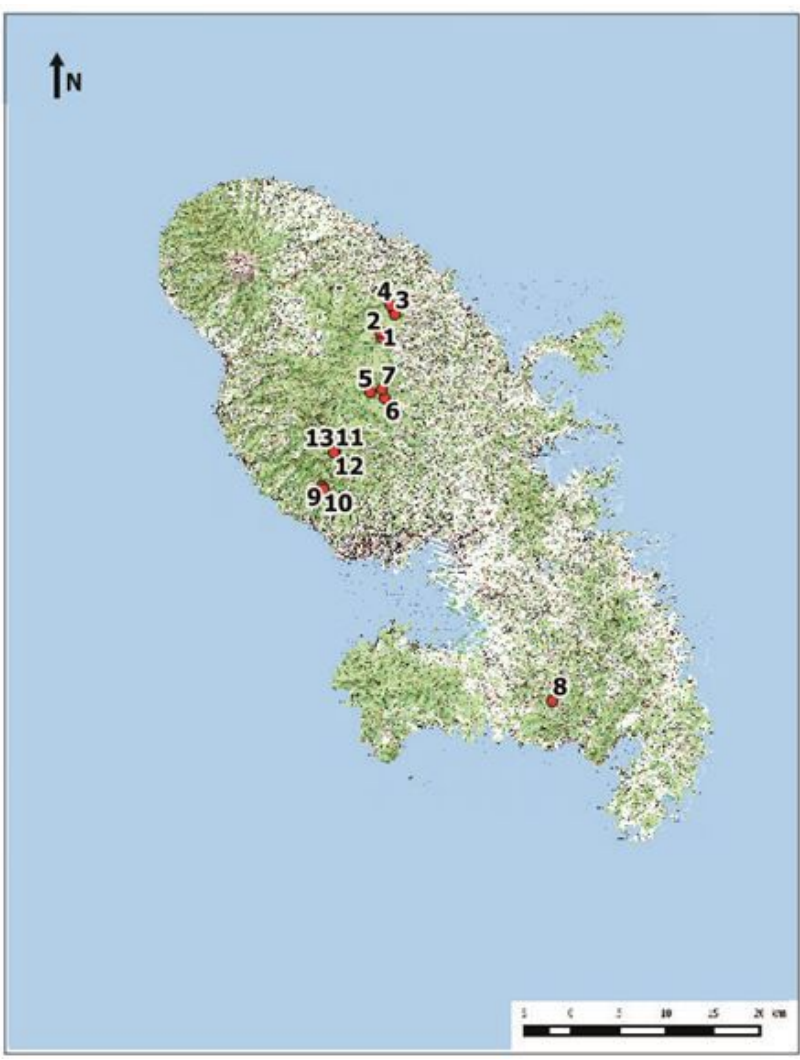

\begin{tabular}{|l|l|}
\hline$X$ & $Y$ \\
\hline $\mathbf{7 0 9 0 3 9}$ & 1632888 \\
\hline $\mathbf{7 0 8 8 8 2}$ & 1633358 \\
\hline $\mathbf{7 1 0 0 8 4}$ & 1634768 \\
\hline $\mathbf{7 0 9 6 6 2}$ & 1635425 \\
\hline $\mathbf{7 0 8 0 8 7}$ & 1628432 \\
\hline $\mathbf{7 0 9 2 7 3}$ & 1628067 \\
\hline $\mathbf{7 0 8 9 6 4}$ & 1628684 \\
\hline $\mathbf{7 2 2 9 2 3}$ & 1603706 \\
\hline $\mathbf{7 0 4 0 8 5 , 8 3}$ & 1620854,73 \\
\hline $\mathbf{7 0 4 2 4 1 , 1 6}$ & 1620652,68 \\
\hline $\mathbf{7 0 5 1 9 3 , 1 3}$ & 1623701,06 \\
\hline $\mathbf{7 0 5 1 2 6 , 3 9}$ & 1623631,19 \\
\hline $\mathbf{7 0 5 1 0 2 , 1 7}$ & 1623653,2 \\
\hline
\end{tabular}




\section{Figure 2}

Survey areas and GPS coordinates (X and $\mathrm{Y})$.

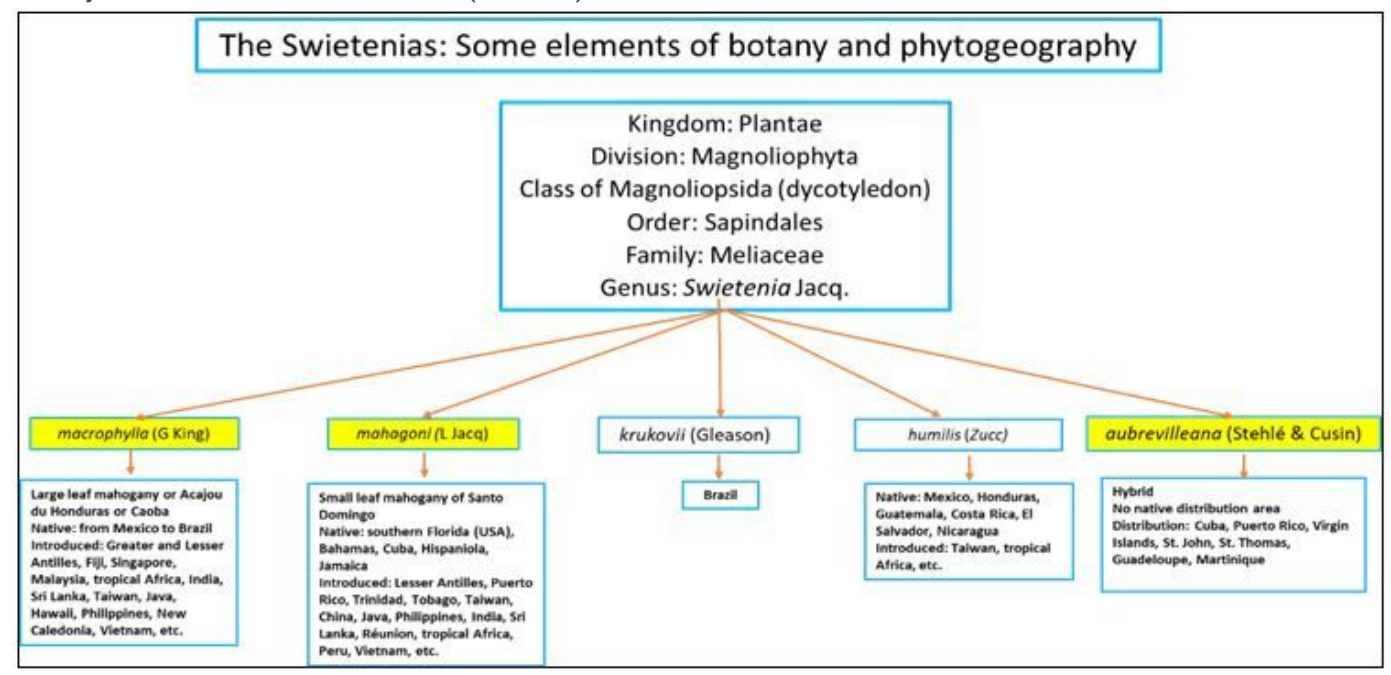

Figure 3

Specific taxonomy and distribution.

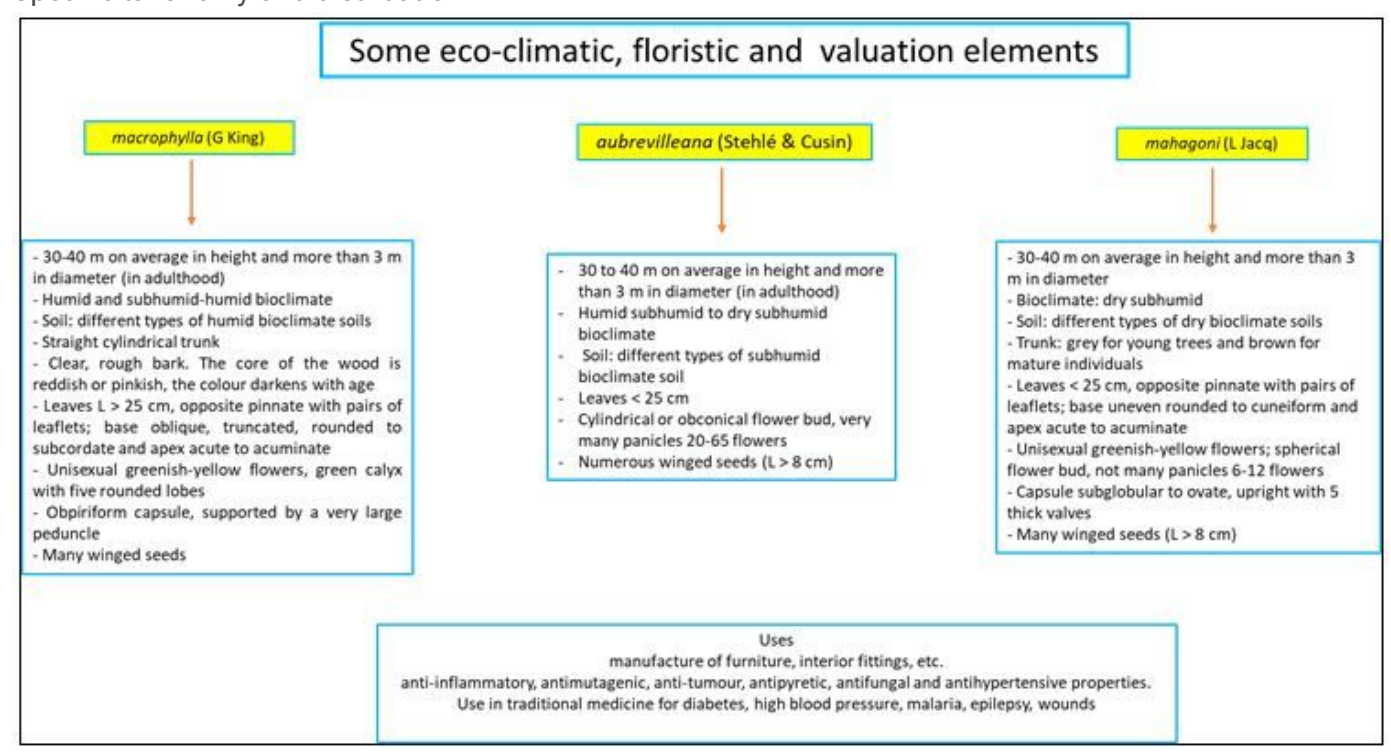

Figure 4

Some eco-climatic, floristic and evaluation features.

\begin{tabular}{|c|c|c|c|c|c|c|c|}
\hline \multicolumn{8}{|c|}{ Transect } \\
\hline 1 & $z$ & 3 & 4 & 5 & . & (............... & . \\
\hline 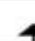 & & & & & & & \\
\hline
\end{tabular}

Figure 5

Unit of floristic surveys and these subdivisions. 


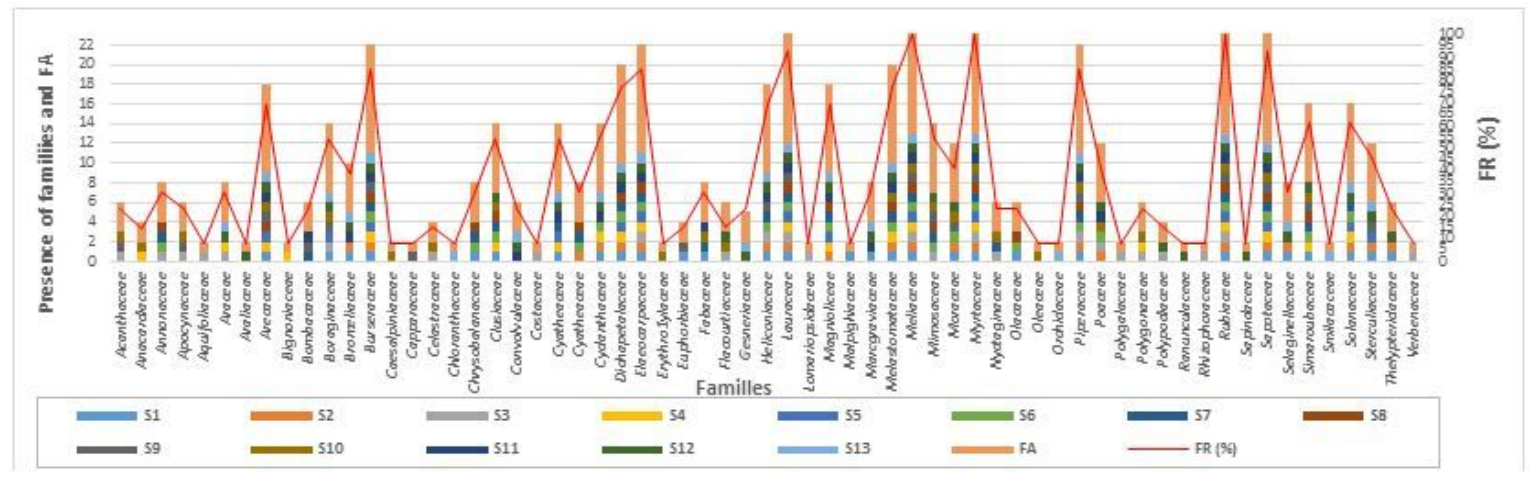

Figure 6

Distribution of families with respect to the different survey stations S1: Gros-Morne 1/ S2 : Gros-Morne 2/ S3 : Montravail/ S4 : Sainte-Marie $1 /$ S5 : Sainte-Marie 2 /S6 : Absalon 1/ S7 : Absalon 2/ S8 : Absalon 3/ S9 : Fond Lahaye 1/ S10 : Fond Lahaye 2/ S11 : Laricher 1/ S12 : Laricher 2/ S13 : Trou matelot. FA: Absolute Frequency (presence = 1, absence $=0) /$ FR: Relative Frequency $[(F A \div 13) \times 100]$.

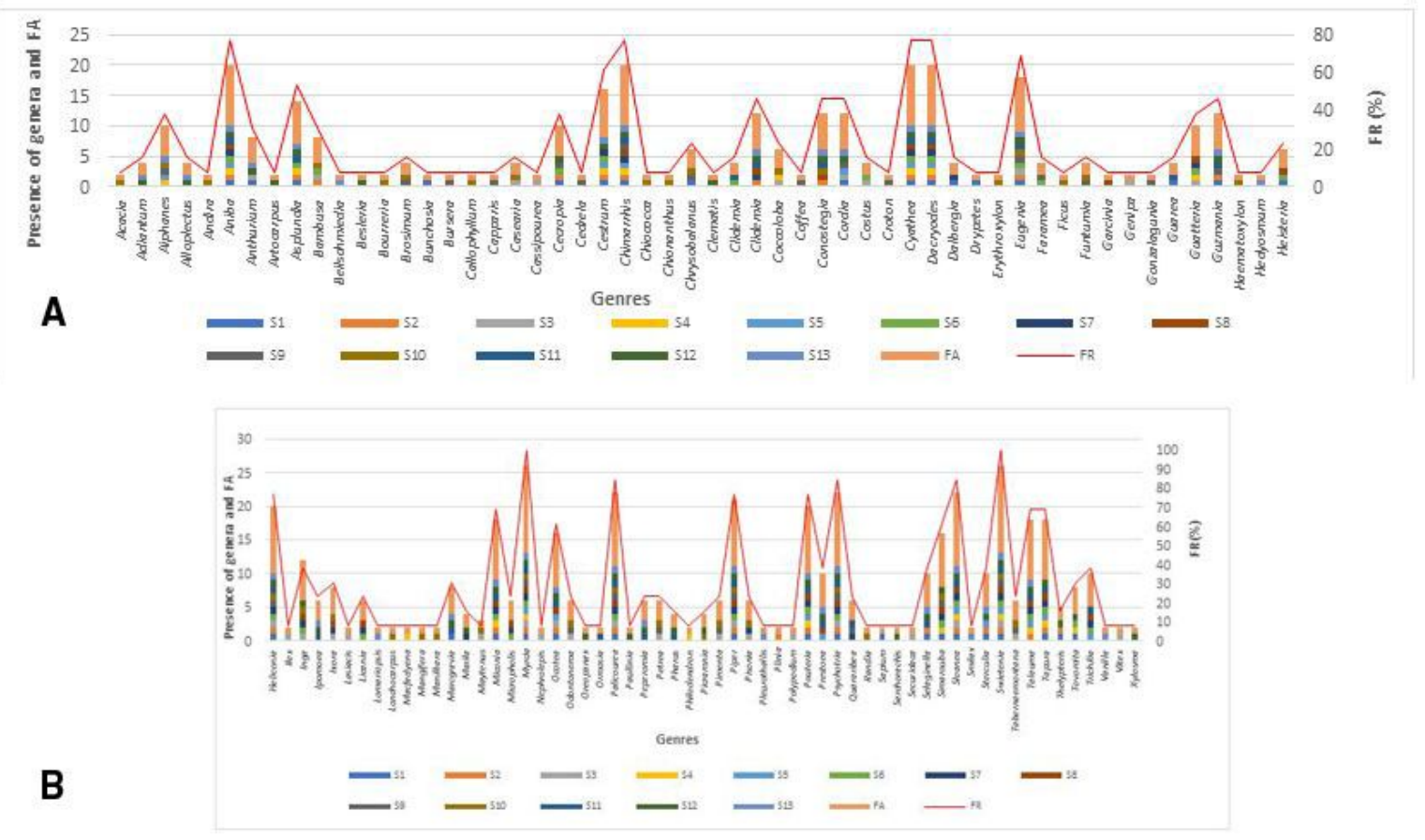

Figure 7

A: Distribution of genres with respect to the various survey stations S1 : Gros-Morne 1/ S2 : Gros-Morne 2/ S3 : Montravail/ S4 : Sainte-Marie $1 /$ S5: Sainte-Marie 2 /S6 : Absalon 1/ S7 : Absalon 2/ S8 : Absalon 3/ S9 : Fond Lahaye 1/ S10 : Fond Lahaye 2/ S11 : Laricher 1/ S12 : Laricher 2/ S13 : Trou matelot. FA: Absolute Frequency (presence = 1, absence $=0) /$ FR: Relative frequency $[(F A \div 13) \times 100]$. B: Distribution of genres with respect to the various survey stations S1: Gros-Morne 1/ S2 : Gros-Morne 2/ S3 : Montravail/ S4 : Sainte-Marie 1/ S5 : Sainte-Marie 2 /S6 : Absalon $1 /$ S7 : Absalon 2/ S8 : Absalon 3/ S9 : Fond Lahaye 1/ S10 : Fond Lahaye 2/ S11 : Laricher 1/ S12 : Laricher 2/ S13 : Trou matelot. FA: Absolute Frequency (presence $=1$, absence $=0) /$ FR: Relative Frequency $[(F A \div 13) \times 100]$. 

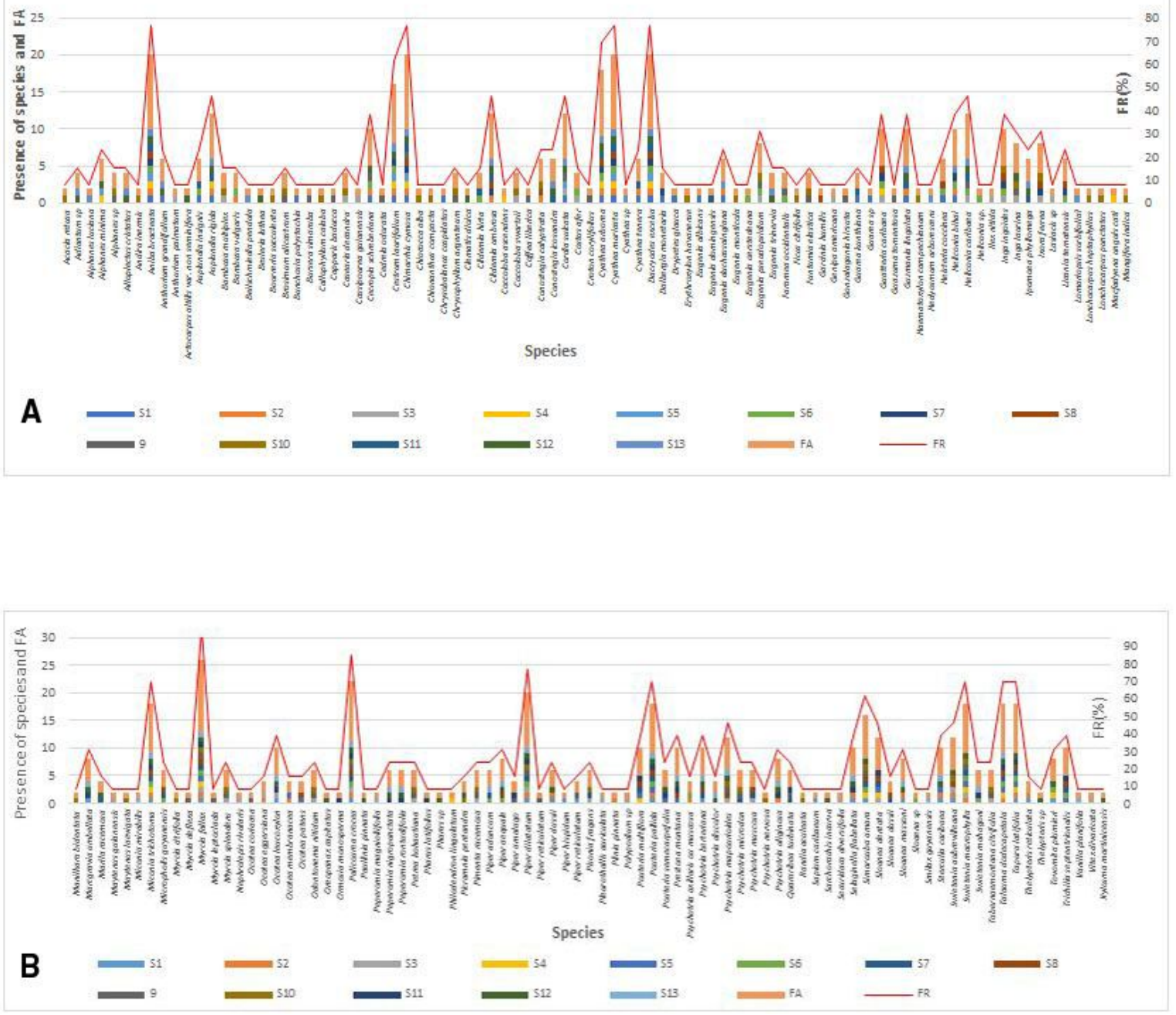

Figure 8

A: Distribution of species with respect to the various survey stations S1 : Gros-Morne 1/ S2 : Gros-Morne 2/ S3 : Montravail/ S4 : Sainte-Marie $1 /$ S5 : Sainte-Marie 2 /S6 : Absalon 1/ S7 : Absalon 2/ S8 : Absalon 3/ S9 : Fond Lahaye 1/ S10 : Fond Lahaye 2/ S11 : Laricher 1/ S12 : Laricher 2/ S13 : Trou matelot. FA: Absolute Frequency (presence $=1$, absence $=0) /$ FR: Relative Frequency $[(F A \div 13) \times 100]$. B: Distribution of species with respect to the various survey stations S1: Gros-Morne 1/ S2 : Gros-Morne 2/ S3 : Montravail/ S4 : Sainte-Marie 1/ S5 : Sainte-Marie 2 /S6 : Absalon 1/ S7 : Absalon 2/ S8 : Absalon 3/ S9 : Fond Lahaye 1/ S10 : Fond Lahaye 2/ S11 : Laricher 1/ S12 : Laricher 2/ S13 : Trou matelot. FA: Absolute Frequency (presence $=1$, absence $=0) /$ FR: Relative Frequency $[($ FA $\div 13) \times 100]$.

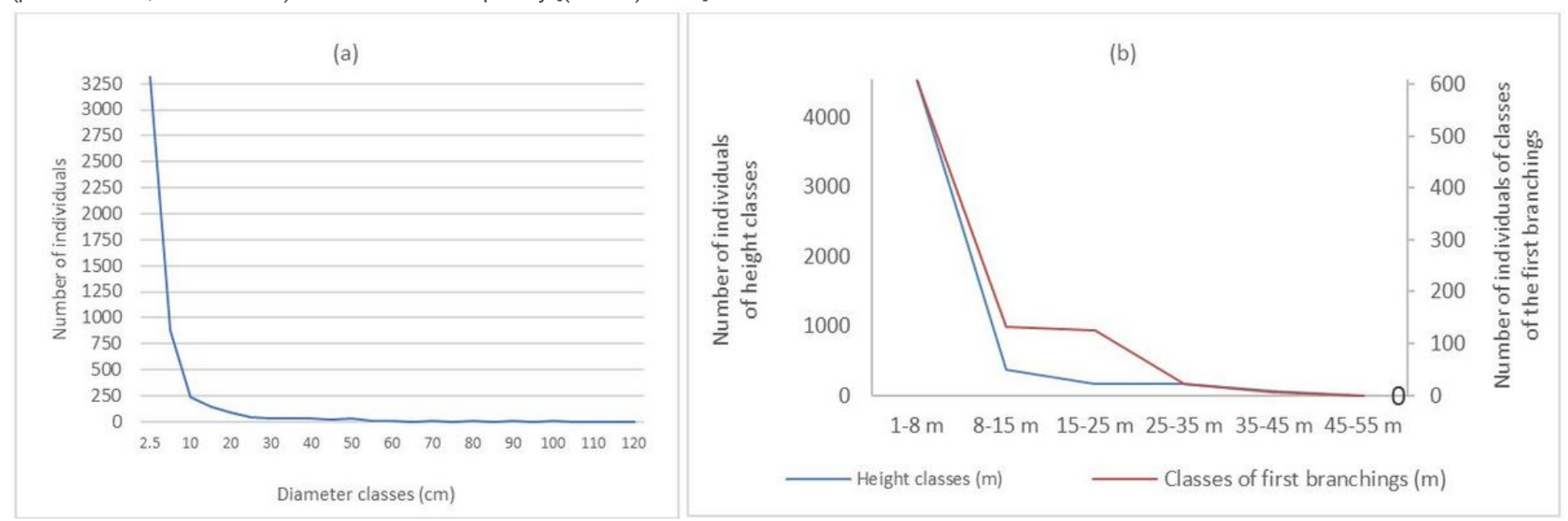

\section{Figure 9}

Populations by class of diameters (a), heights (b) and first branchings (b). 

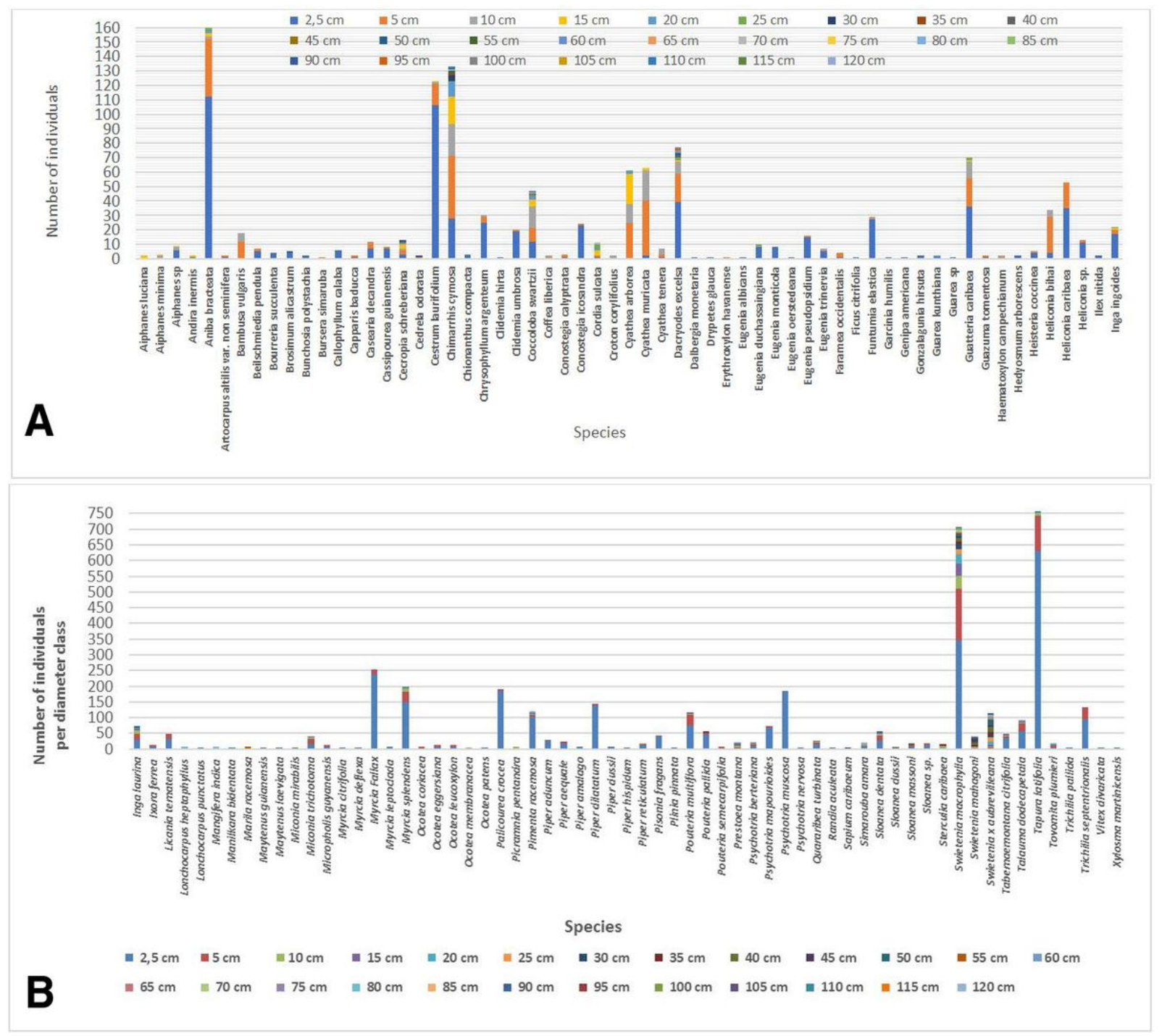

Figure 10

A: Specific populations by diameter class. B: Specific populations by diameter class. 

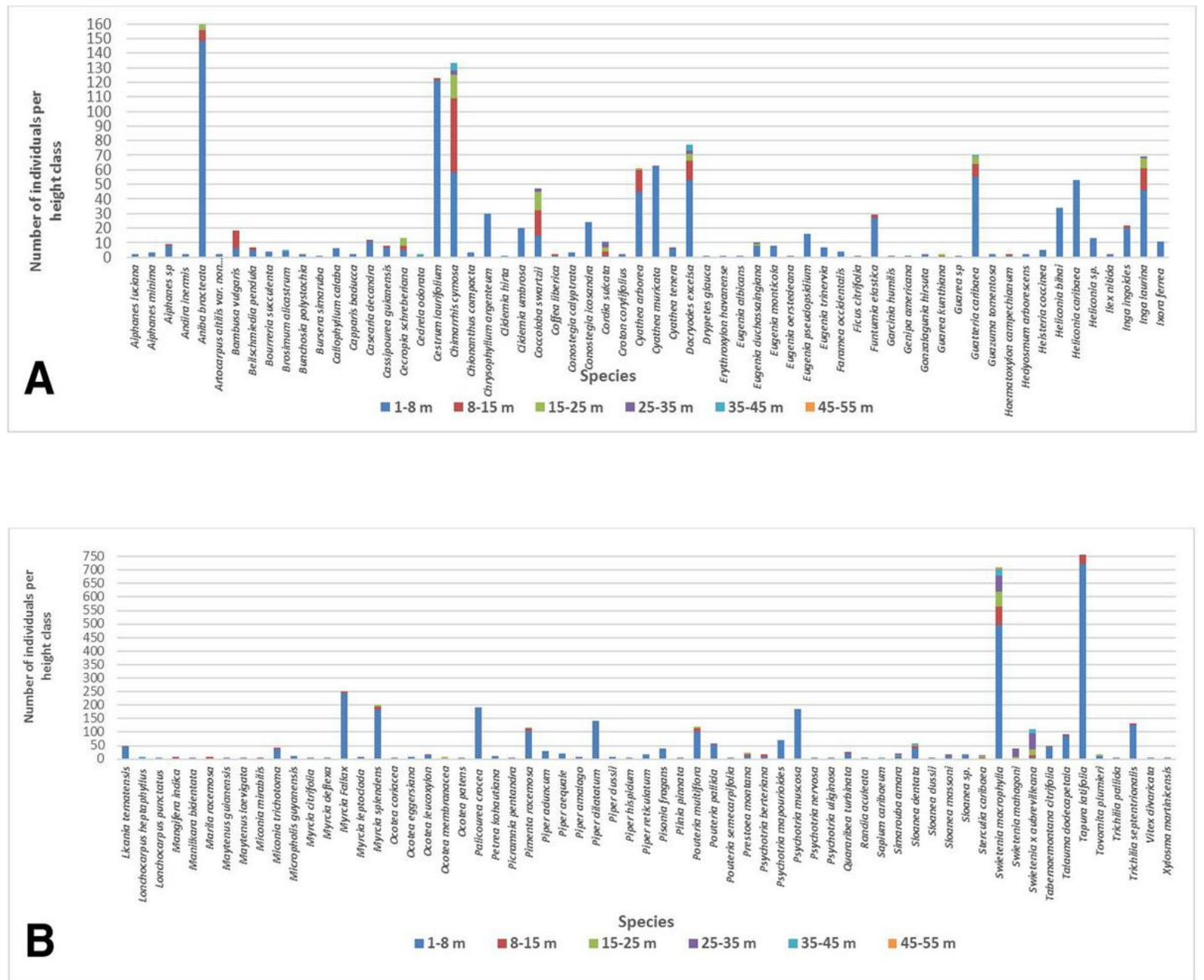

Figure 11

A: Specific populations by height class. B: Specific populations by height class.

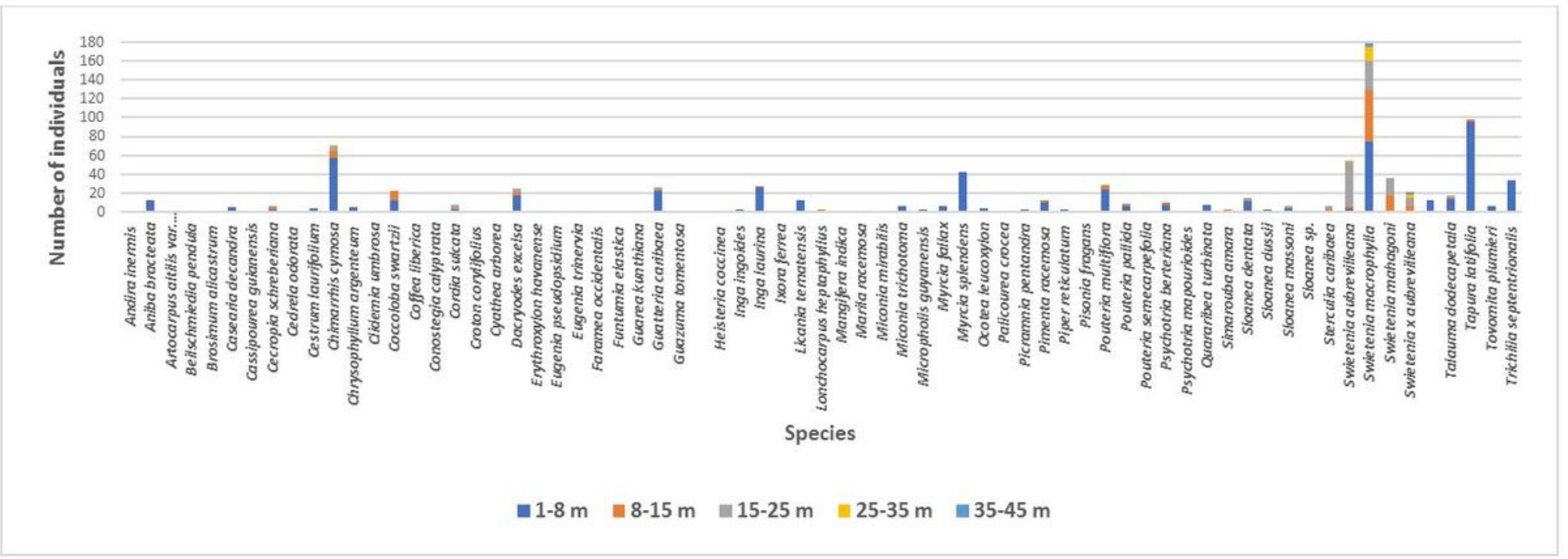

Figure 12

Specific populations by classes of first branchings of individuals in phases of maturity or morphogenetic development. 


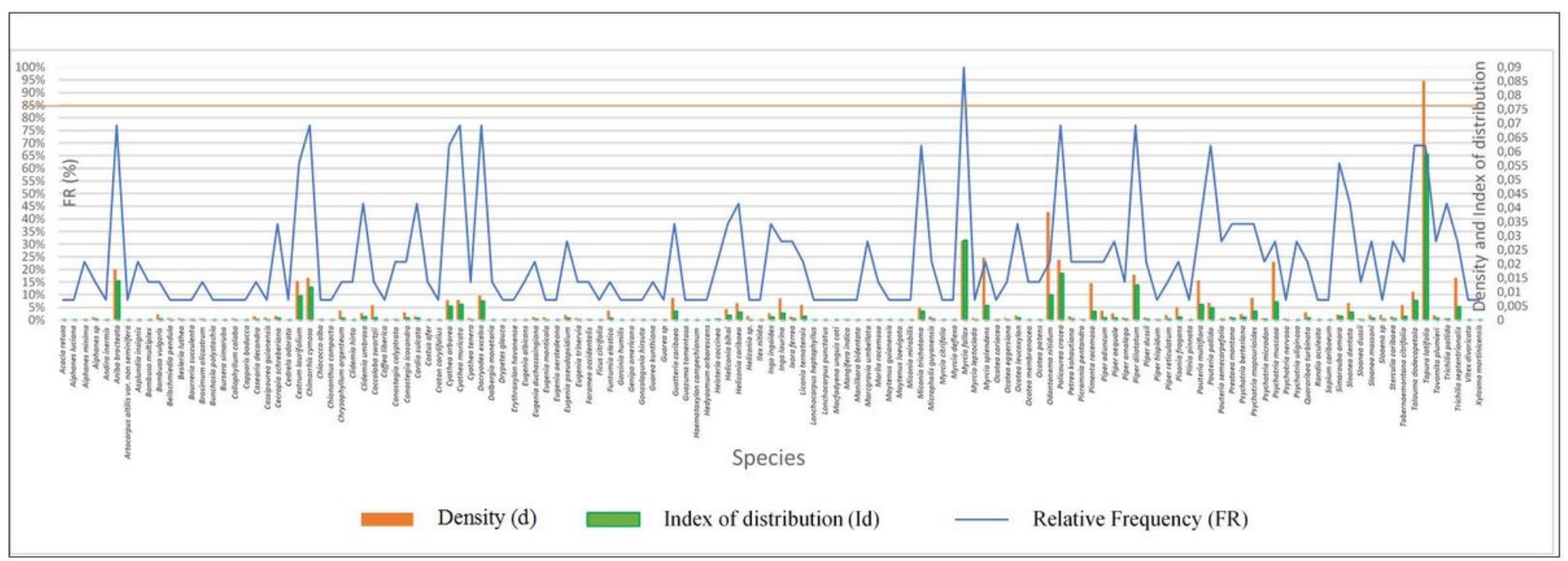

Figure 13

Specific variation of the Relative Frequency, density and Index of distribution [herbaceous and ligneous types (bushes, trees and lianas) /FR=FA $\div 13$ (Stations) / FA: Absolute Frequency corresponding to the number of species present in respect to the survey stations / $d=$ number of individuals per $\mathrm{m}^{2}$ (total area of the thirteen stations). Id=FR $\times d$.

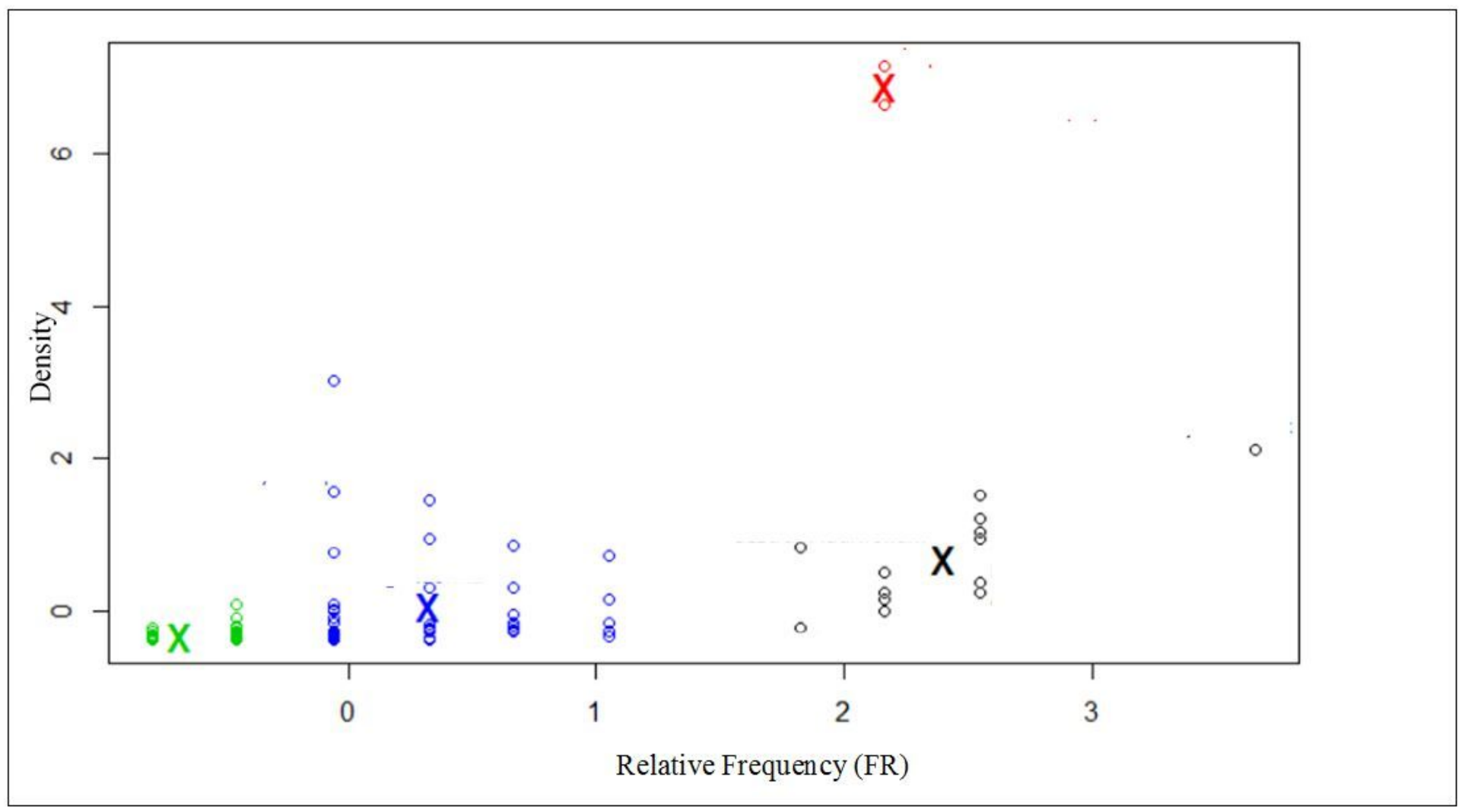

Figure 14

Socio-biological differentiations of the species (See Annex 1). 


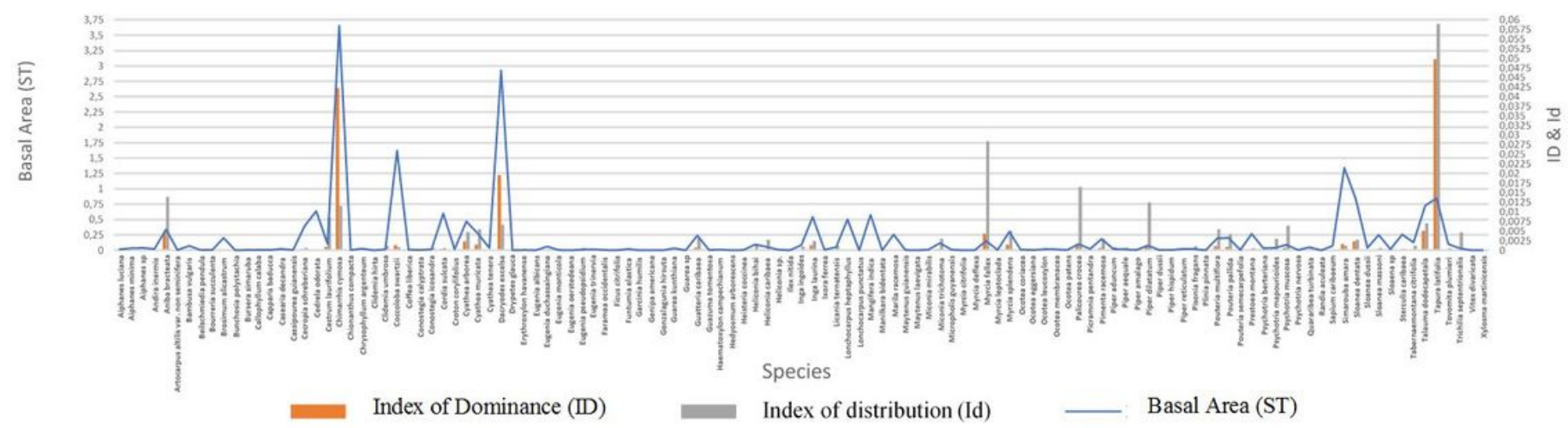

\section{Figure 15}

Specific variation of the basal area, the index of distribution and the index of dominance (trees and bushes).

A

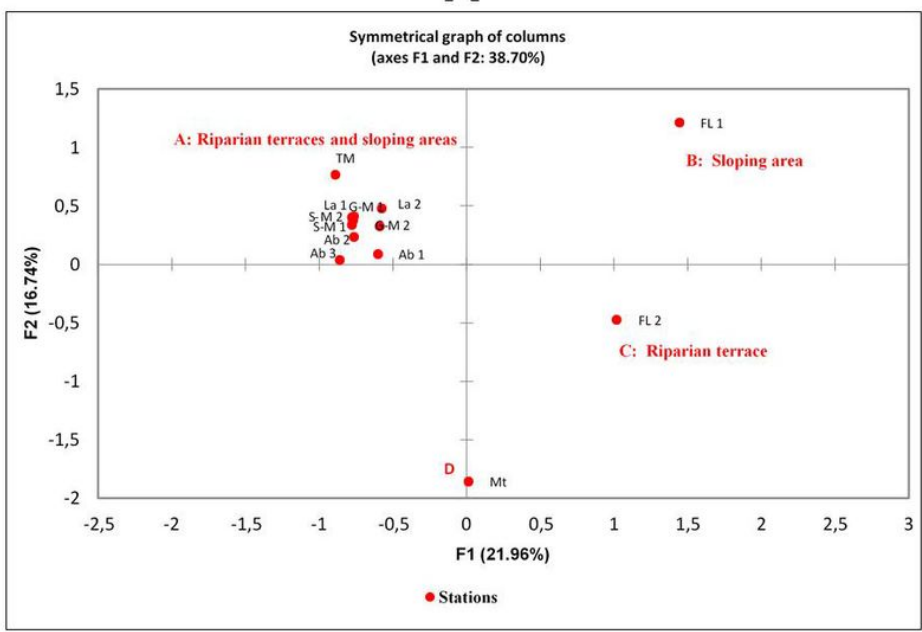

B

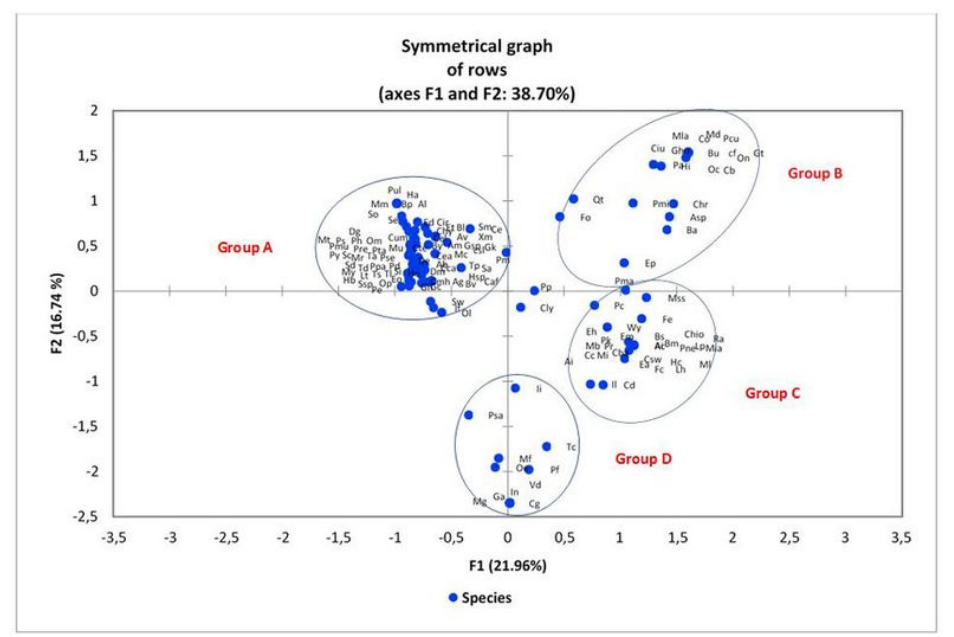

Figure 16

A: Bioclimatic affinities of the stations (see Table 1). B: Ecosystemic affinity of the species (Box1). 


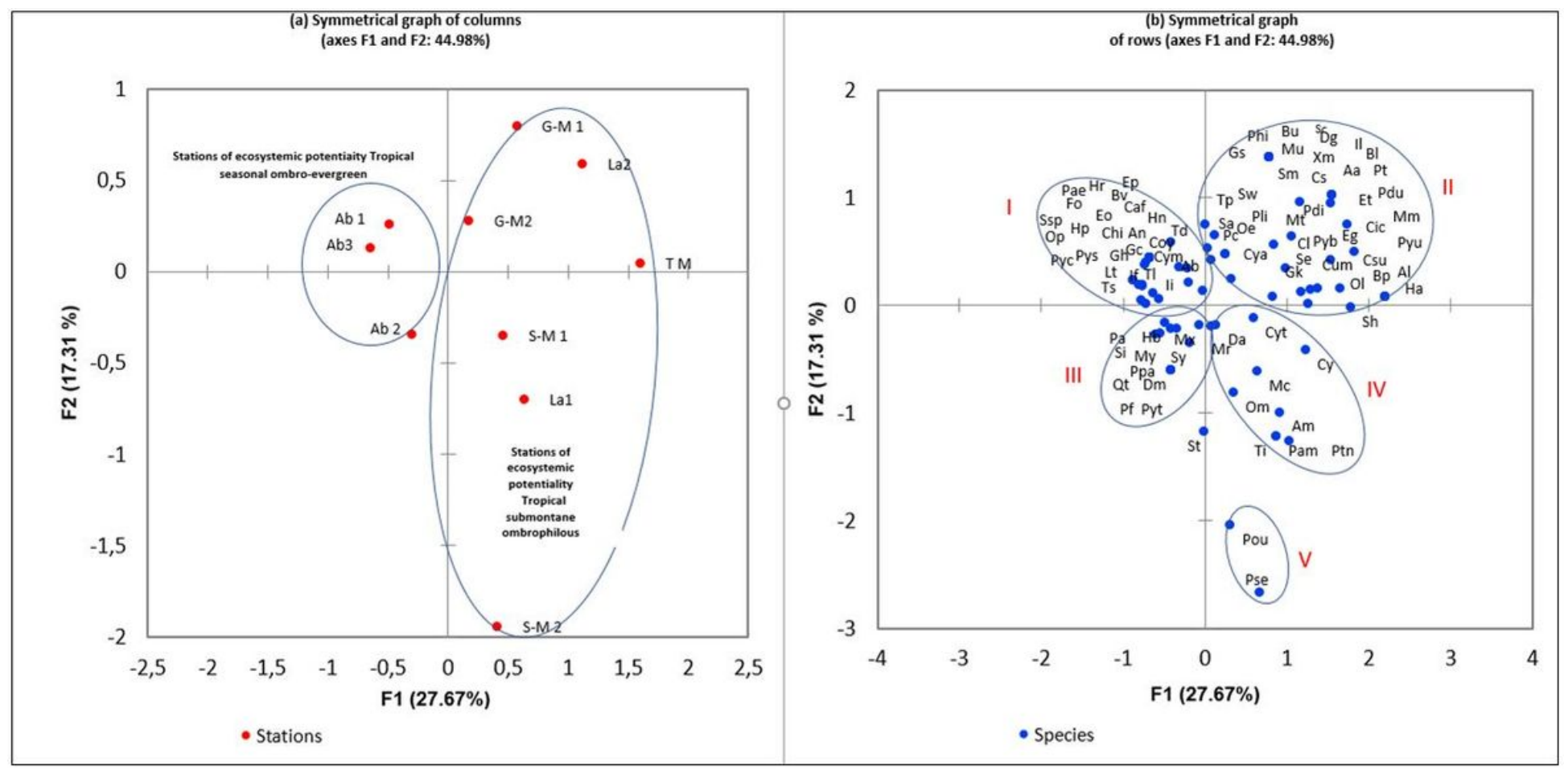

Figure 17

Biodemographic differentiation [a: Stational, b: Specific (Box 2)]

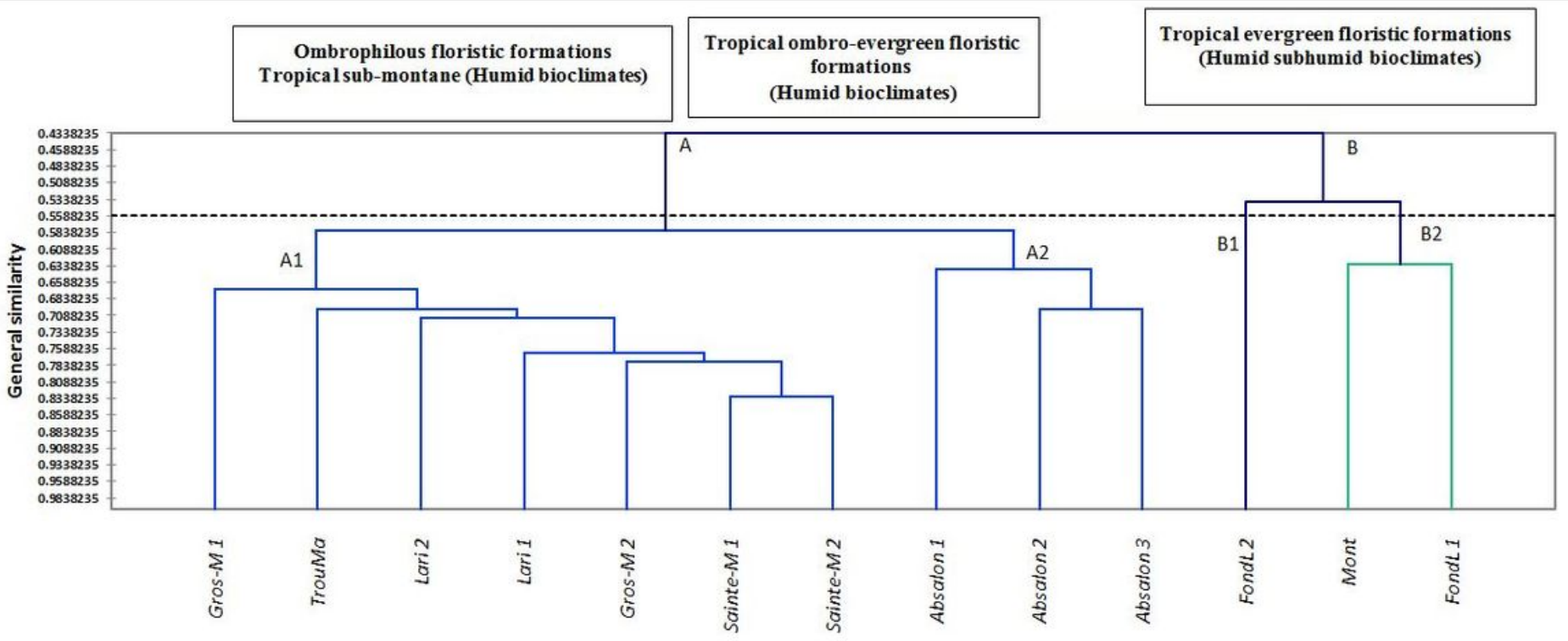

\section{Figure 18}

Biodemographic similarity of the stations. 


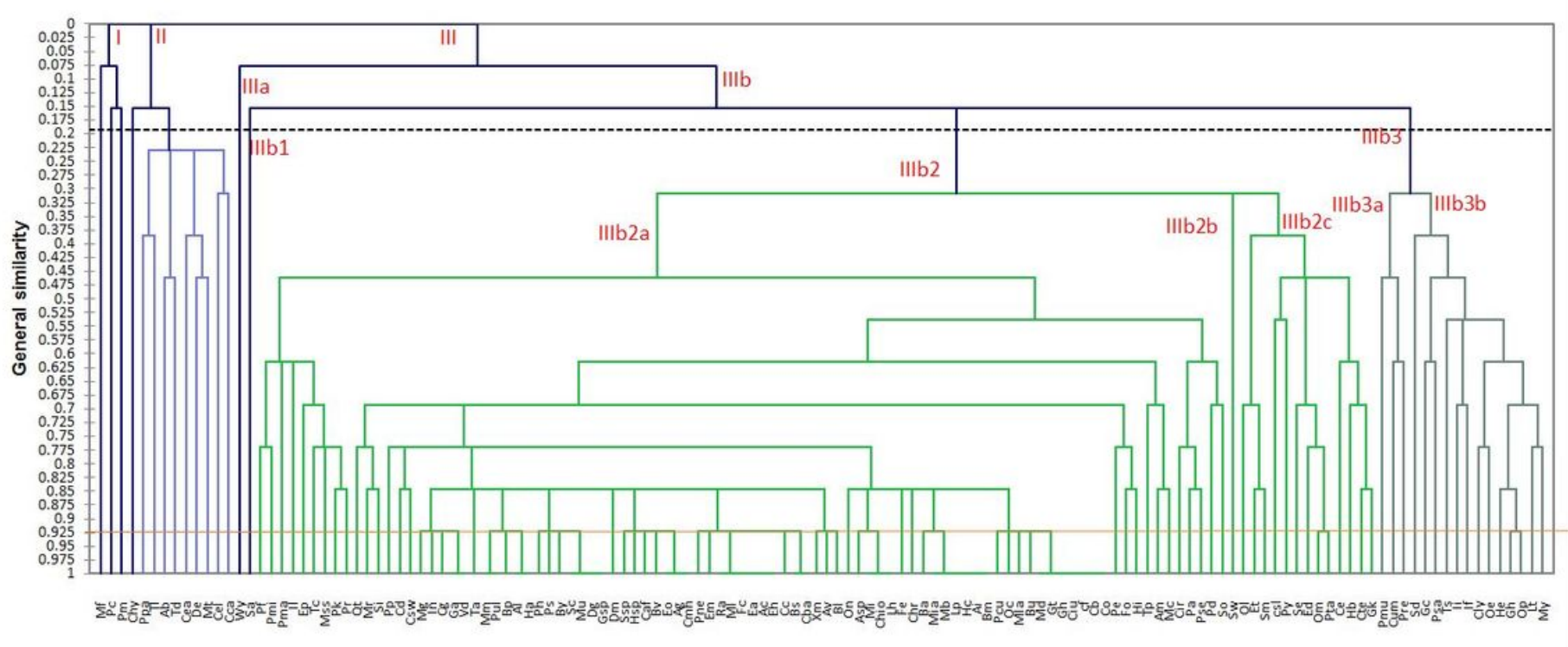

Figure 19

Populational similarity of the species (see Box 1).

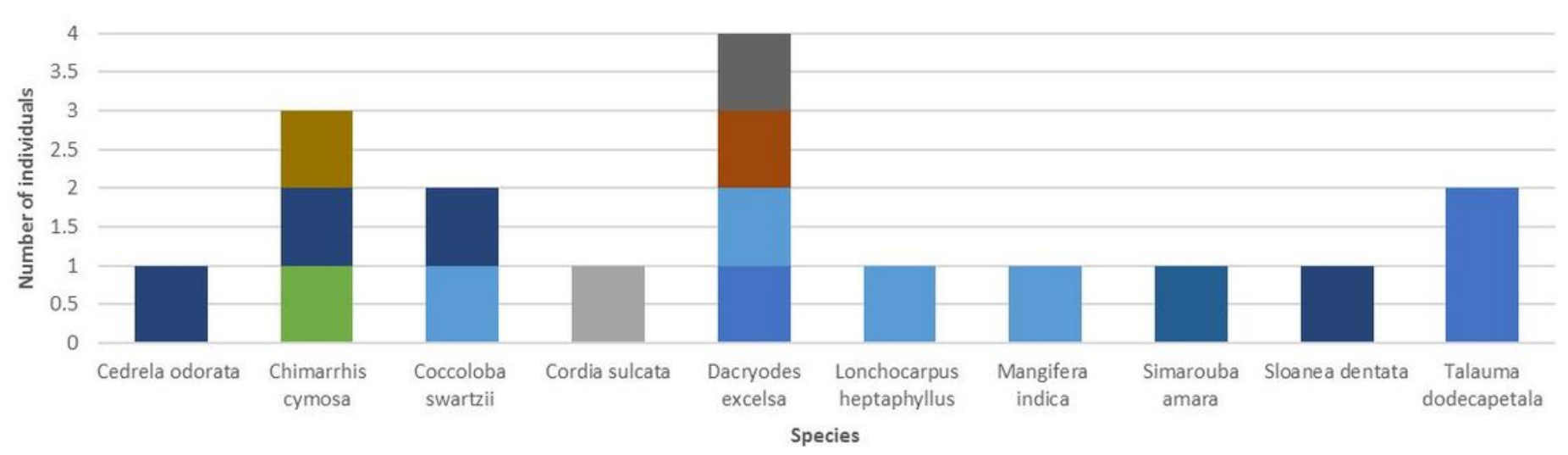

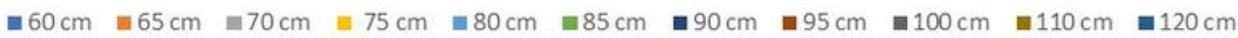

\section{Figure 20}

Relictual adult trees from old forest matrices or windthrow.

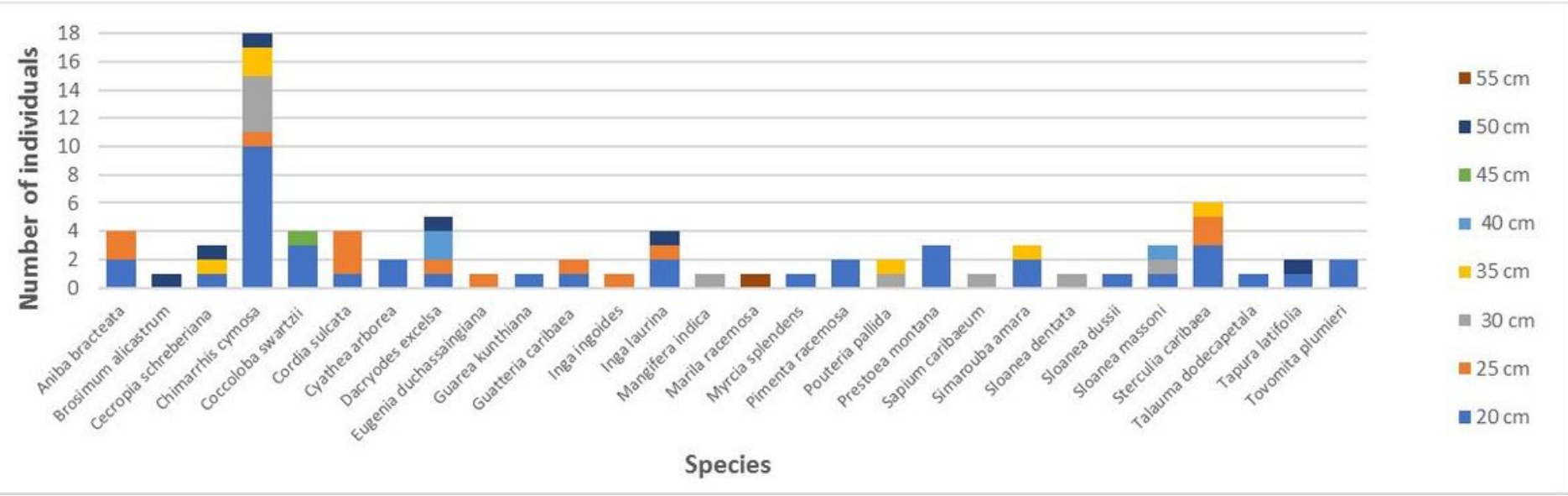

Figure 21

Page $24 / 25$ 
Forest matrix or gap trees: mature or at different stages of morphological development.

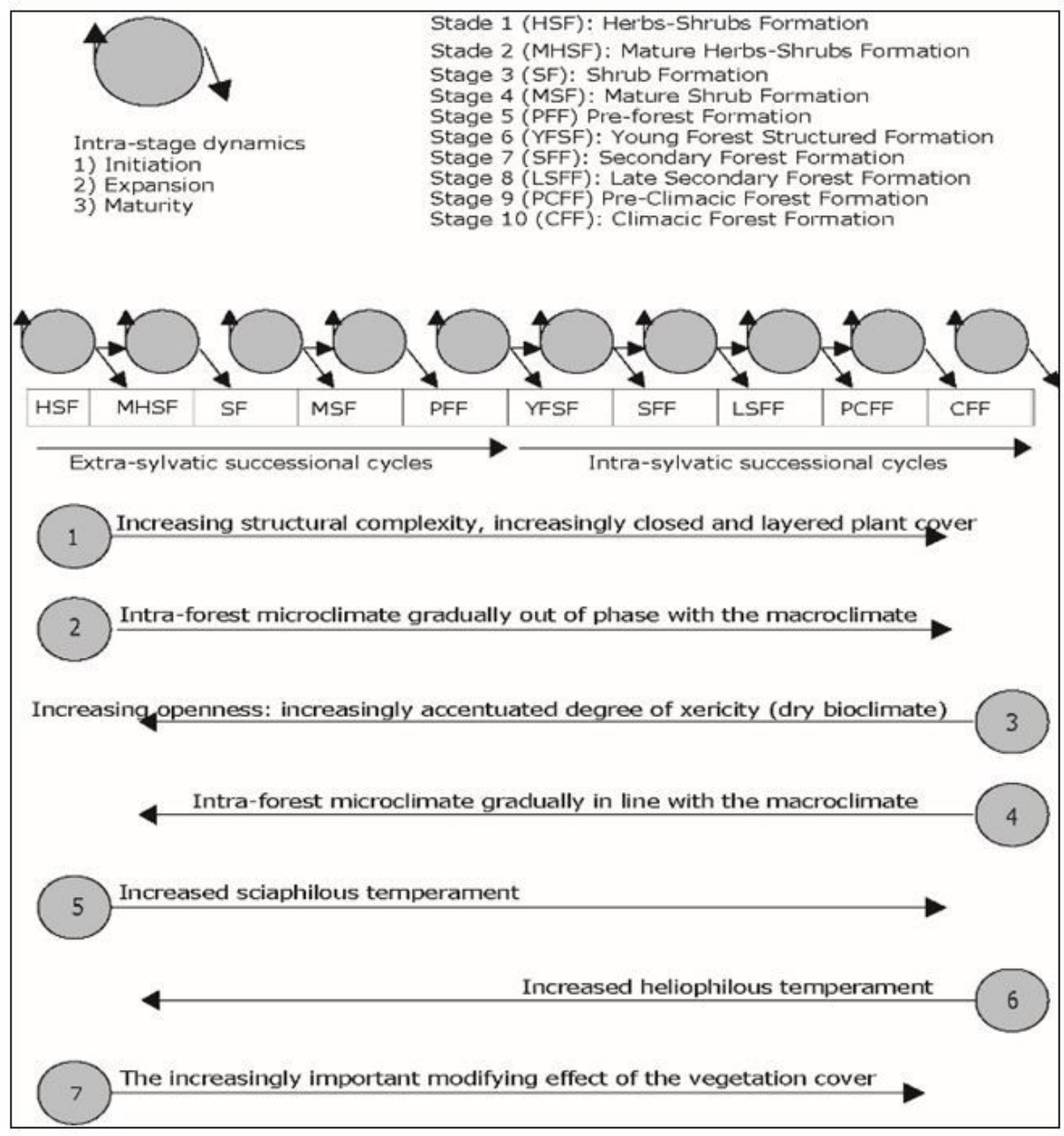

\section{Figure 22}

Descriptive model of plant dynamics in the Lesser Antilles. 